\title{
Synthesis, characterization, and immune efficacy of layered double hydroxide@SiO nanoparticles with shell-core structure as a delivery carrier for Newcastle disease virus DNA vaccine
}

\author{
This article was published in the following Dove Press journal: \\ International Journal of Nanomedicine \\ 13 April 2015 \\ Number of times this article has been viewed
}

\author{
Kai Zhaol,* \\ Guangyu Rong ${ }^{1,2, *}$ \\ Chen Guo' \\ Xiaomei Luo' \\ Hong Kang' \\ Yanwei Sun ${ }^{1,3}$ \\ Chunxiao Dai ${ }^{4}$ \\ Xiaohua Wang' \\ Xin Wang \\ Zheng Jin ${ }^{4}$ \\ Shangjin Cui ${ }^{3}$ \\ Qingshen Sun'
}

'Key Laboratory of Microbiology, School of Life Science, Heilongjiang University, Harbin, People's Republic of China;

${ }^{2}$ Department of Avian Infectious Disease, Shanghai Veterinary Research Institute of Chinese Academy of Agricultural

Sciences, Shanghai, People's Republic of China; ${ }^{3}$ Division of Swine Infectious

Diseases, State Key Laboratory of

Veterinary Biotechnology, Harbin Veterinary

Research Institute of Chinese Academy

of Agricultural Sciences, Harbin, People's

Republic of China; ${ }^{4}$ Key Laboratory

of Chemical Engineering Process and

Technology for High-efficiency Conversion,

Heilongjiang University, Harbin, People's

Republic of China

*These authors contributed equally to this work

Correspondence: Kai Zhao/Qingshen Sun Laboratory of Microbiology, College of Life Science, Heilongjiang University, 74 Xuefu

Road, Nangang District, Harbin I50080,

People's Republic of China

Tel +8645 I 86608586

Fax +8645186609016

Email zybin395@I26.com;

sunqingshen@hlju.edu.cn
Abstract: Layered double hydroxide (LDH)@ $\mathrm{SiO}_{2}$ nanoparticles were developed as a delivery carrier for the plasmid DNA expressing the Newcastle disease virus F gene. The LDH was hydrotalcite-like materials. The plasmid DNA encapsulated in the $\mathrm{LDH} @ \mathrm{SiO}_{2}$ nanoparticles (pFDNA-LDH@SiO $-\mathrm{NPs}$ ) was prepared by the coprecipitation method, and the properties of pFDNA-LDH@ $\mathrm{SiO}_{2}$-NPs were characterized by transmission electron microscopy, zeta potential analyzer, Fourier transform infrared spectroscopy, and X-ray diffraction analysis.

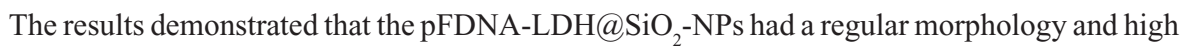
stability with a mean diameter of $371.93 \mathrm{~nm}$, loading capacity of $39.66 \% \pm 0.45 \%$, and a zeta potential of $+31.63 \mathrm{mV}$. A release assay in vitro showed that up to $91.36 \%$ of the total plasmid DNA could be sustainably released from the pFDNA-LDH@SiO $-\mathrm{SPs}_{2}$ within 288 hours. The LDH@ $\mathrm{SiO}_{2}$ nanoparticles had very low toxicity. Additionally, their high transfection efficiency in vitro was detected by fluorescent microscopy. Intranasal immunization of specific pathogenfree chickens with pFDNA-LDH@ $\mathrm{SiO}_{2}$-NPs induced stronger cellular, humoral, and mucosal immune responses and achieved a greater sustained release effect than intramuscular naked plasmid DNA, and the protective efficacy after challenge with the strain $\mathrm{F}_{48} \mathrm{E}_{9}$ with highly virulent (mean death time of chicken embryos $\leq 60$ hours, intracerebral pathogenicity index in 1 -day-old chickens >1.6) was 100\%. Based on the results, $\mathrm{LDH} @ \mathrm{SiO}_{2}$ nanoparticles can be used as a delivery carrier for mucosal immunity of Newcastle disease DNA vaccine, and have great application potential in the future.

Keywords: $\mathrm{LDH} @ \mathrm{SiO}_{2}$ nanoparticles, Newcastle disease, mucosal immunity, Cytotoxicity, IgA

\section{Introduction}

Newcastle disease (ND) is a highly pathogenic viral disease of avian species. ${ }^{1}$ The disease continues to negatively impact poultry producers by infecting birds worldwide. ${ }^{2}$ The causative agent of ND is an ND virus (NDV). ${ }^{3}$ All strains of NDV belong to the family Paramyxoviridae and consist of single-stranded, non-segmented, and negative-sense RNA genomes. NDV has six genes that produce six structural proteins, ie, fusion (F), hemagglutinin-neuraminidase (HN), RNA-dependent RNA (large) polymerase (L), nucleocapsid $(\mathrm{N})$, phosphoprotein $(\mathrm{P})$, and the matrix $(\mathrm{M}){ }^{4}$ The F protein is supposed to play a major role in the virulence of NDV strains. It allows the binding and fusion of NDV to the host cell membrane, enabling the virus to enter host cells and induces immunity. ${ }^{5}$

Currently, vaccine immunization is still an effective way to resist NDV infection. The NDV-attenuated live vaccines and inactivated vaccines have played an important 
role in prevention and control of ND. However, these conventional vaccines have several disadvantages, such as poor immunogenicity, partial virus toxicity reservation, and induction of respiratory pathological changes. DNA vaccination was supposed to be a promising strategy for activating immune responses against NDV infection. ${ }^{6}$ Since the discovery of gene immunization in 1990, genes from different viruses have been delivered into animals, showing satisfactory effects. ${ }^{7,8}$ Therefore, DNA vaccines have become popular in the field. The plasmid carrier used in construction of a DNA vaccine should replicate in Escherichia coli in high copy and express the gene efficiently within the animal body. Currently, DNA vaccines are administered in the form of either aqueous solutions or lyophilized powders. However, because of their high hydrophilicity and therefore a low distribution coefficient between oil and water phases, ${ }^{9,10}$ it is difficult for DNA vaccines to transfer across cell membranes after intramuscular injection, limiting the amount of vaccine to be captured by antigen-presenting cells to induce immune responses. ${ }^{11}$ Other factors that limit the clinical applications of these novel DNA vaccines include the difficulties associated with DNA stability and delivery, resulting in low levels of DNA vaccine expression and weak immune responses, ${ }^{12-14}$ especially in large animal models. ${ }^{15}$ Therefore, effective strategies which can improve the efficacy of DNA vaccines, such as the use of a powerful adjuvant to enhance immunogenicity, optimization of the delivery methods, and selection of suitable target for effective antigen presentation, etc, are desirable. ${ }^{16,17}$

With the development of nanotechnology and antigen delivery systems, biomaterials-based nanoparticles (NPs) can offer several advantages over the limitations of other traditional antigen delivery systems. These include stabilization of antigen, delivery of antigen, fewer probable side effects, and activation of innate immunity. ${ }^{18}$ Many structurally stable materials have been investigated for drug delivery. For instance, silica materials, which are biocompatible, have been the representative materials to enable the biological use of inorganic NPs. ${ }^{19-21}$ It has been shown that silica is able to store and gradually release such therapeutic drugs as antibiotics and proteins in the controlled release applications. ${ }^{22-24}$ Furthermore, silica has been used to improve the biocompatibility of some drug delivery systems, such as magnetic NPs, ${ }^{25-27}$ biopolymers, ${ }^{28}$ and micelles. ${ }^{29}$

Layered double hydroxide (LDH), commonly known as hydrotalcite-like materials and anionic clays, is a family of layered nanomaterials that has been widely applied in catalysts, absorption, pharmaceutics, and photochemistry. In recent years, the synthesis of LDH-based nanocomposites has received much attention because of the potential uses of nanocomposite-based engineering materials. ${ }^{30}$ The use of $\mathrm{LDH}$ materials in preparing polymer nanocomposites is a new field. LDH is a host-guest material consisting of positively charged metal hydroxide sheets with intercalated anions and water molecules. The formula of $\mathrm{LDH}$ molecules can be expressed as follows: $\left[\mathrm{M}^{2+}{ }_{1-x} \mathrm{M}^{3+} x(\mathrm{OH})_{2}\right]^{\mathrm{x}+} \mathrm{A}^{\mathrm{n}-}{ }_{x / \mathrm{n}} \cdot m \mathrm{H}_{2} \mathrm{O}$, where $\mathrm{M}^{2+}$ and $\mathrm{M}^{3+}$ are divalent and trivalent metal ions, respectively, $\mathrm{A}^{\mathrm{n}-}$ is an interchangeable compensating anion entrapped in the interlayer space, $m$ is the number of molecules of co-intercalated water per formula weight of the compound, and $x$ is defined as the $\mathrm{M}^{3+} /\left(\mathrm{M}^{2+}+\mathrm{M}^{3+}\right)$ ratio. ${ }^{31}$ Over the past decade, LDHs have attracted much attention in drug delivery and gene therapy owing to their good biocompatibility, no toxicity, and controlled release property. Yuan and Shi synthesized LDH nanofiller (LDH-SA). The nanofiller was used to prepare a UV-cured exfoliated polymer/ LDH nanocomposite, which possesses the combined advantages of both LDH and silsesquioxane. ${ }^{32}$ Kang et al found that the LDH nanosheets could be stabilized by alginate molecules in aqueous media and that the LDH nanosheets in the nanocomposites could be redispersed in aqueous media. ${ }^{33}$

Recently, nanocomposite materials with shell-core structure produced by combining two kinds of nanometer materials have received much attention, as these materials incorporate the virtues of the individual materials. In this study, LDH@SiO_-NPs with shell-core structures were developed to encapsulate the F gene of NDV into a eukaryotic expression plasmid $\mathrm{pVAX} 1-\mathrm{F}(\mathrm{o})$ by a coprecipitation method for enhancing the efficacy of a DNA vaccine against NDV. The bioactivity and safety of the resulting NPs (pFDNALDH@ $\mathrm{SiO}_{2}-\mathrm{NPs}$ ) were studied by in vitro transfection and cytotoxicity analyses. In addition, we assessed the ability of the pFDNA-LDH@ $@ \mathrm{SiO}_{2}-\mathrm{NPs}$ to induce immune responses and protect specific pathogen-free (SPF) chickens from NDV infection after intranasal administration. We found that the carrier has the advantage of $\mathrm{LDH}$ to protect the plasmid DNA against nuclease degradation, realizing the long-acting mechanism of DNA vaccine within the chicken's body.

\section{Materials and methods Preparation of the plasmid DNA encapsulated in the $\mathrm{SiO}_{2} \mathrm{NPs}$}

The eukaryotic expression plasmid pVAX1-F(o) DNA that carries the F gene of NDV was provided by the State Key Laboratory of Veterinary Biotechnology, Harbin Veterinary Research Institute of Chinese Academy of Agricultural Sciences, Harbin, People's Republic of China. Extraction 
and purification of a large amount of the plasmid DNA were carried out as previously described. ${ }^{34,35}$ Ninety milliliters of anhydrous ethanol, $12.5 \mathrm{~mL}$ of deionized water, and $2.0 \mathrm{~mL}$ of ammonia water were added to a $120 \mathrm{~mL}$ beaker. The reaction mixture was vigorously stirred using a magnetic stirrer at room temperature, followed by adding $10 \mathrm{~mL}$ of tetraethyl orthosilicate and stirring at $200 \mathrm{rpm}$ for 2 hours at room temperature. Then, $\mathrm{SiO}_{2}$ NPs were collected by centrifugation, washed three times with anhydrous ethanol, and desiccated in the air.

$\mathrm{SiO}_{2}$ NPs (145 mg) were added into the $1.0 \%$ 3-aminopropyl-triethoxysilane (APTES) ethanol solution, and the reaction mixture was then stirred at room temperature for 12 hours. The APTES-SiO 2 -NPs were precipitated with anhydrous ethanol and dried as described above.

The plasmid DNA-loaded NPs were developed as follows (Figure S1): $4 \mathrm{mg}$ of APTES-SiO 2 -NPs were added into $4 \mathrm{~mL}$ of phosphate-buffered saline (PBS) buffer ( $\mathrm{pH}$ 7.4), and $0.01 \mathrm{~mL}$ of plasmid DNA was then pipetted to the reaction mixture. The mixture was incubated at room temperature for 15 minutes. The NPs were collected by centrifugation at $10,000 \mathrm{rpm}$ and $4^{\circ} \mathrm{C}$ for 15 minutes and then washed with PBS three times. The plasmid DNA-loaded NPs, ie, pFDNA$\mathrm{SiO}_{2}$-NPs, were obtained.

The $\mathrm{pFDNA}-\mathrm{SiO}_{2}-\mathrm{NPs}_{\mathrm{S}}$ were prepared by mixing APTES$\mathrm{SiO}_{2}$-NPs and DNA in PBS ( $\mathrm{pH}$ 7.4) at different mass ratios $(w / w)$ with a final DNA concentration of $24,510.9 \mathrm{ng} / \mu \mathrm{L}$. The mixture was incubated at room temperature for 15 minutes. The connection of NPs with the plasmid was detected by agarose gel electrophoresis, which was run with a $0.8 \%$ agarose gel at $90 \mathrm{~V}$ for 20 minutes. The mixture was then incubated at room temperature for 48 hours and centrifuged at 10,000 rpm and $4{ }^{\circ} \mathrm{C}$ for 10 minutes. The precipitates were collected, then washed with PBS buffer (pH 7.4) twice and TE buffer once, followed by centrifugation at $10,000 \mathrm{rpm}$ and $4{ }^{\circ} \mathrm{C}$ for 10 minutes. In order to prove that the $\mathrm{SiO}_{2}$ can bind with plasmid DNA and release DNA completely, the supernatant solution underwent agarose gel electrophoresis using $0.8 \%(\mathrm{w} / \mathrm{v})$ gel containing ethidium bromide at $90 \mathrm{~V}$ for 20 minutes.

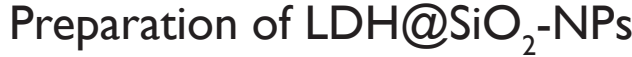 encapsulating plasmid DNA}

LDH@ $\mathrm{SiO}_{2}$-NPs encapsulating plasmid DNA were prepared via the following procedures with two solutions.

\section{Solution I}

For solution I, $6.3 \mathrm{~g} \mathrm{NaOH}, 9.1 \mathrm{~g} \mathrm{NaNO}_{3}$, and $0.8 \mathrm{~g}$ pFDNA$\mathrm{SiO}_{2}-\mathrm{NPs}$ were dissolved together in deionized water with a final volume of $72 \mathrm{~mL}$.

\section{Solution II}

For solution II, $0.06 \mathrm{~mol} / \mathrm{L} \mathrm{Mg}\left(\mathrm{NO}_{3}\right)_{2} \cdot 6 \mathrm{H}_{2} \mathrm{O}$ and $0.03 \mathrm{~mol} / \mathrm{L}$ $\mathrm{Al}\left(\mathrm{NO}_{3}\right)_{3} \cdot 9 \mathrm{H}_{2} \mathrm{O}$ were dissolved together in deionized water with a final volume of $63 \mathrm{~mL}$. Solution II was slowly dripped into solution I and stirred at $200 \mathrm{rpm}$ at room temperature for 2.5 hours. All the operational procedures were done under $\mathrm{N}_{2}$ protection to avoid oxidation. The pFDNA-LDH@SiO $\mathrm{Si}_{2}$ NPs were rinsed with deionized water and dried at room temperature.

\section{Characterization of the pFDNA-LDH@ $\mathrm{SiO}_{2}-\mathrm{NPs}$}

Morphology and loading capacity

The prepared pFDNA-SiO $-\mathrm{NPs}_{2}$ and pFDNA-LDH@SiO $\mathrm{SiO}_{2}^{-}$ NPs were visualized through transmission electron microscopy (TEM) (JEM-200EX; Hitachi Ltd., Tokyo, Japan) to assess their morphological and surface characteristics. ${ }^{36}$ The particle size and zeta potentials of both pFDNA-SiO NPs and pFDNA-LDH@SiO $\mathrm{Si}_{2}$-NPs were measured using a Zeta Sizer 2000 from Malvern Instruments (Malvern, UK). The loading capacity (LC) of the pFDNA-LDH@ $\mathrm{SiO}_{2}-\mathrm{NPs}$ was calculated as follows: ${ }^{37}$

$$
\mathrm{LC}(\%)=\left(\mathrm{W}_{0}-\mathrm{W}_{1}\right) / \mathrm{W}_{\mathrm{N}} \times 100 \% \text {, }
$$

where $\mathrm{W}_{0}$ is the total amount of the plasmid DNA added, $\mathrm{W}_{1}$ is the amount of free plasmid DNA released from the pFDNA-LDH@ $\mathrm{SiO}_{2}-\mathrm{NPs}$, and $\mathrm{W}_{\mathrm{N}}$ is the weight of the pFDNA-LDH@SiO ${ }_{2}$-NPs. All the measurements were performed in triplicate.

\section{Fourier transform infrared spectroscopy and X-ray diffraction analyses of the LDH and pFDNA-LDH@SiO,-NPs}

The changes in the major groups of the LDH and pFDNALDH@SiO $-\mathrm{SPs}_{2}$ were characterized through Fourier transform infrared spectroscopy (FTIR) (Spectrum One; PerkinElmer Inc., Waltham, MA, USA). Analysis of the $\mathrm{X}$-ray diffraction (XRD) was performed using a D8 Advance diffractometer (Bruker Optik GmbH, Ettlingen, Germany) with $\mathrm{Cu}$ target and $\mathrm{K} \alpha$ radiation $(\lambda=0.15418 \mathrm{~nm})$ at $40 \mathrm{kV}$ and $50 \mathrm{~mA}$. The $2 \theta$ angle was scanned between $5^{\circ}$ and $80^{\circ}$ at $25^{\circ} \mathrm{C}$.

\section{In vitro release of the pFDNA-LDH@ $\mathrm{SiO}_{2}-\mathrm{NPs}$}

The in vitro cumulative release of the plasmid DNA from the pFDNA-LDH@ $\mathrm{SiO}_{2}$-NPs was studied by the Coomassie 
Brilliant Blue G-250 method. Briefly, $0.1 \mathrm{~g}$ of dried pFDNA-LDH@SiO_-NPs was fully mixed with $1.0 \mathrm{~mL}$ of PBS buffer ( $\mathrm{pH} \mathrm{7.4)}$ and stirred at $180 \mathrm{rpm}$ and $4^{\circ} \mathrm{C}$. At the predetermined time intervals $(0,6,12,24,36,48,72,96,120$, $144,168,192,216,240,264$, and 288 hours), $100 \mu \mathrm{L}$ of sample solution was taken away and the same volume of fresh PBS was added. The sample was centrifuged at $10,000 \mathrm{rpm}$ and $4^{\circ} \mathrm{C}$ for 10 minutes. The concentration of the plasmid DNA in the supernatant was determined with an ultraviolet spectrophotometer. The release curve of plasmid DNA from pFDNA-LDH@, $\mathrm{SiO}_{2}$-NPs was derived by plotting the release time on the $\mathrm{x}$-axis against the amount of plasmid DNA accumulatively released from pFDNA-LDH@ $\mathrm{SiO}_{2}-\mathrm{NPs}$ on the y-axis.

\section{In vitro expression of the pFDNA- LDH@SiO $-\mathrm{NPs}$}

293 T cells, human embryonic kidney cells which were transformed with SV40T antigen, were incubated in a sixwell plate at $37^{\circ} \mathrm{C}$ with $5 \% \mathrm{CO}_{2}$ until the cell growth reached $80 \%$ confluence for subsequent use. The cells underwent the following treatments: 1) naked DNA control treatment, in which $4 \mu \mathrm{g}$ DNA was incubated with the cells according to the instructions of a Lipofectamine ${ }^{\mathrm{TM}} 2000$ reagent kit; 2) pFDNA-LDH@ $@ \mathrm{SiO}_{2}-\mathrm{NP}$ treatment. The pFDNA-LDH@ $\mathrm{SiO}_{2}$-NPs containing $4 \mu \mathrm{g}$ of plasmid DNA were added and incubated with the cells for 5 hours; 3) blank LDH@ $\mathrm{SiO}_{2}-$ NPs control, in which $\mathrm{LDH} @ \mathrm{SiO}_{2}$ at the amount equivalent to that in pFDNA-LDH@SiO $\mathrm{SiO}_{2}$-NPs was added and incubated with the cells for 5 hours; and 4) cell control, in which Dulbecco's Modified Eagle's Medium (DMEM) containing $1 \%$ serum was added. After being initially transfected, the cells were incubated for 72 hours in DMEM containing 1\% serum. All the transfection experiments were performed in triplicate.

\section{Evaluation of the safety of the pFDNA- LDH@SiO $-\mathrm{NPs}$}

In vitro cytotoxicity of the pFDNA-LDH@SiO $-\mathrm{NPs}$ In vitro cytotoxicity of the pFDNA-LDH@ $\mathrm{SiO}_{2}-\mathrm{NPs}_{\mathrm{s}}$ evaluated as described previously. ${ }^{36,38}$ Chicken embryo kidney cells were first cultured in DMEM, then diluted to the final cell concentration of $2 \times 10^{6}$ cells $/ \mathrm{mL}$, transferred to 96-well plates at $200 \mu \mathrm{L}$ perwell, and cultured at $37^{\circ} \mathrm{C}$ for 5 hours. After discarding the supernatant in the wells, $50 \mu \mathrm{L}$ of pFDNA-LDH@ $\mathrm{SiO}_{2}$-NPs (diluted in DMEM culture at $1 \mathrm{mg} / \mathrm{mL}$ ) was added into the wells, followed by incubation at $37^{\circ} \mathrm{C}$ for 2 hours. Then, $10 \mu \mathrm{L}$ of WST- 8 reagents was added and incubated for 5 hours. The 96-well plates were read at $450 \mathrm{~nm}$ with a microplate reader.
The survival rate of the cells was calculated as described previously. ${ }^{36}$

\section{Safety of the pFDNA-LDH@SiO $-\mathrm{NPs}_{2}$}

Fifteen 7-day-old SPF chickens obtained from Harbin Veterinary Research Institute Laboratory Animal Center (Harbin, People's Republic of China) were randomly divided into three groups: chickens in group 1 were immunized intramuscularly (IM) with the pFDNA-LDH@ $\mathrm{SiO}_{2}$-NPs containing $2 \mathrm{mg}$ of the plasmid DNA; chickens in group 2 were immunized intranasally (IN) with the pFDNA-LDH@ $\mathrm{SiO}_{2}-\mathrm{NPs}$ containing $2 \mathrm{mg}$ of the plasmid DNA; and chickens in group 3 were immunized IM with the PBS solution as control group. These three groups of chickens were bred under the same conditions. Any behavioral abnormalities in the chickens, including feed intake, water intake, and mental state, were continuously observed and recorded for 3 weeks.

\section{Immunization of SPF chickens}

A total of 100 4-week-old SPF chickens were randomly divided into five groups with 20 chickens per group. The chickens in groups 1,2, and 3 were treated with PBS buffer, blankLDH@ $\mathrm{SiO}_{2}$-NPs IM, and $200 \mu \mathrm{g}$ of naked plasmid DNA $(0.1 \mathrm{~mL})$ IM, respectively. Chickens in groups 4 and 5 were treated with 0.2 mL of pDNA-LDH@SiO $-\mathrm{SPs}_{2}$ containing $200 \mu \mathrm{g}$ of plasmid DNA IM and IN, respectively. Booster immunization was performed 14 days later with the same doses. Care of laboratory animals and experimentation on animals were in accordance with animal ethics guidelines and approved protocols. All animal studies were approved by the Animal Ethics Committee of the Harbin Veterinary Research Institute of the Chinese Academy of Agricultural Sciences (CAAS), China (SCXK [H] 2013-001).

\section{Detection of IgG antibody in the serum of the immunized chickens}

Blood samples were collected from the wing veins of chickens in the five groups at $7,14,21,28,35,42,49$, and 56 days after the first treatment. The serum samples were obtained by centrifugation at $3,000 \mathrm{rpm}$ and $4^{\circ} \mathrm{C}$ for 10 minutes. The titer of the NDV-specific IgG in sera was estimated by hemagglutination inhibition test.

\section{Detection of IgA antibody in mucosa extracts of the immunized chickens}

Serum, tracheal fluid, bile, and Harderian glands were collected from two chickens from each of the five groups immunized at $7,14,21,28,35,42,49$, and 56 days after 
the first treatment. IgA antibody was detected by enzymelinked immunosorbent assay (ELISA) sandwich technique according to the instruction manual of an NDV IgA ELISA Kit (Rapidbio Co, Ltd, West Hills, USA). Briefly, samples were added to microtiter plates coated with purified antigen, followed by adding standard and HRP-labeled antigen. The reaction was stopped by addition of $3,3^{\prime}, 5,5^{\prime}$ tetramethylbenzidine, and the absorbance at $450 \mathrm{~nm}$ was measured with a microplate reader.

\section{Lymphocyte proliferation in the immunized chickens}

To assess the cellular immune responses of the immunized chickens at 7, 14, 21, 28, 35, and 42 days after the first treatment, lymphocyte proliferation of the immunized chickens was assayed by 3-(4, 5)-dimethylthiahiazo (-z-y1)-3, 5-diphenytetrazoliumromide (MTT) colorimetric assay as described previously. ${ }^{36}$ The stimulation index (SI) was determined using the following formula: ${ }^{39}$

$$
\mathrm{SI}=\mathrm{OD} 570 \mathrm{~T} / \mathrm{OD} 570 \mathrm{C} \text {, }
$$

where OD570 $\mathrm{T}$ is the mean value of the tested groups (pFDNA-LDH@SiO 2 -NPs IN, pFDNA-LDH@ $@ \mathrm{SiO}_{2}-\mathrm{NPs}$ IM, naked plasmid pVAX1-F(o) IM, blank LDH@ $\mathrm{SiO}_{2}-\mathrm{NPs}$ $\mathrm{IM})$ and OD570 $\mathrm{C}$ is the mean value of the control group (PBS IM).

\section{Protective efficacy}

The ability of pFDNA-LDH@ $\mathrm{SiO}_{2}$-NPs to protect chickens against the infection of NDV strain $\mathrm{F}_{48} \mathrm{E}_{9}$ was determined. Strain $\mathrm{F}_{48} \mathrm{E}_{9}$ is highly virulent (mean death time of chicken embryos $\leq 60$ hours, intracerebral pathogenicity index in 1 -day-old chickens $>1.6$ ). Protection was determined as described previously. ${ }^{36}$ Five chickens were randomly selected from every immunized group when the level of NDV-specific antibody in serum was increased to $6.0 \log 2$. The chickens infected IM with $0.1 \mathrm{~mL}$ of the highly virulent NDV strain $\mathrm{F}_{48} \mathrm{E}_{9}$ had a viral titer of $10^{4.5} 50 \%$ egg infectious dose $/ 0.1 \mathrm{~mL}$ for challenge studies. The clinical signs of illness and death were monitored daily for 35 days. The infected chickens and the corresponding negative control chickens were euthanized. Their duodena and myocardia were collected and examined by histological staining.

\section{Statistical analysis}

All experiments were performed in triplicate. Data were presented as mean values \pm standard deviation. Mean values were analyzed using the one-sided Student's $t$-test. The significance level was set at $P<0.05$.

\section{Results \\ Characterization of the pFDNA- $\mathrm{SiO}_{2}-\mathrm{NPs}$}

Physical features of NP-based vaccines such as particle size, morphology, and charge distributions contribute greatly to the efficacy of vaccination. As shown in Figure 1A, a spherical and uniform-size nature was revealed for the typical pFDNA$\mathrm{SiO}_{2}-\mathrm{NPs}$ by TEM. The prepared NPs had uniform morphology and good dispersion. Measurement of these particles showed a relatively narrow size distribution of $90 \pm 11 \mathrm{~nm}$ (Figure 1B). The zeta potential of $\mathrm{SiO}_{2} \mathrm{NPs}$, APTES-SiO NPs, and pFDNA-SiO ${ }_{2}$-NPs were $-21.08 \mathrm{mV},+28.37 \mathrm{mV}$, and $+11.43 \mathrm{mV}$, respectively.

Figure 2A shows the agarose gel electrophoresis image for the pFDNA-SiO $-\mathrm{NP}_{2}$ complexes, which demonstrated the ability of $\mathrm{SiO}_{2}$ NPs to immobilize DNA with high efficiency. Through changing the number of particles, we could adjust the amounts of DNA binding to the particle surface.

Figure $2 \mathrm{~B}$ shows that lanes 2-8 clearly had plasmid DNA binding equivalent to the control in lane 1, demonstrating that the DNA can be stabilized and released from the pFDNA$\mathrm{SiO}_{2}$-NP complexes after being placed at room temperature for 48 hours and that the integrity of plasmid DNA could be maintained.

The ability of the $\mathrm{SiO}_{2}$ to protect the plasmid DNA from DNase I degradation was demonstrated by the fact that $\mathrm{SiO}_{2}$ encapsulation could protect the plasmid DNA from DNase I digestion (Figure 2C, lanes 2-8), but the naked plasmid DNA was completely degraded by DNase I (Figure 2C, lane 1), suggesting that the encapsulation of plasmid DNA into $\mathrm{SiO}_{2}$ may ensure the effective entry and high stability of plasmid DNA in the mucosal environment.

\section{Characterization of the pFDNA-LDH@ $\mathrm{SiO}_{2}-\mathrm{NPs}$}

Size and zeta potential analysis

Typical pFDNA-SiO $-\mathrm{NPs}_{2}$ LDH, and pFDNA-LDH@ $\mathrm{SiO}_{2}-\mathrm{NPs}$ showed a uniform appearance as revealed by TEM (Figure 3). The pFDNA-SiO $-\mathrm{NPs}_{2}$ were round with good dispersion (Figure 3A). Plain LDH NPs were thin, hexagonal, and plate-like in shape (Figure 3B) with sizes in the range from 78 to $207 \mathrm{~nm}$, an average particle size of $99.1 \mathrm{~nm}$, and zeta potential of $31.47 \mathrm{mV}$ (Figure $4 \mathrm{~A}$ ). Figure $3 \mathrm{C}$ shows that the addition of $0.7 \mathrm{~g}$ of $\mathrm{pFDNA}-\mathrm{SiO}_{2}-\mathrm{NPs}$ caused the loss of the core from the core-shell structure. Figure 3E shows that addition of $0.9 \mathrm{~g}$ of $\mathrm{pFDNA}-\mathrm{SiO}_{2}-\mathrm{NPs}$ could result in too much core. The addition of $0.8 \mathrm{~g}$ of $\mathrm{pFDNA}-\mathrm{SiO}_{2}-\mathrm{NPs}_{\mathrm{s}}$ could produce effective coating (Figure 3D), and the shell LDH had no obvious plate-like structure but was coated on the surface 
A

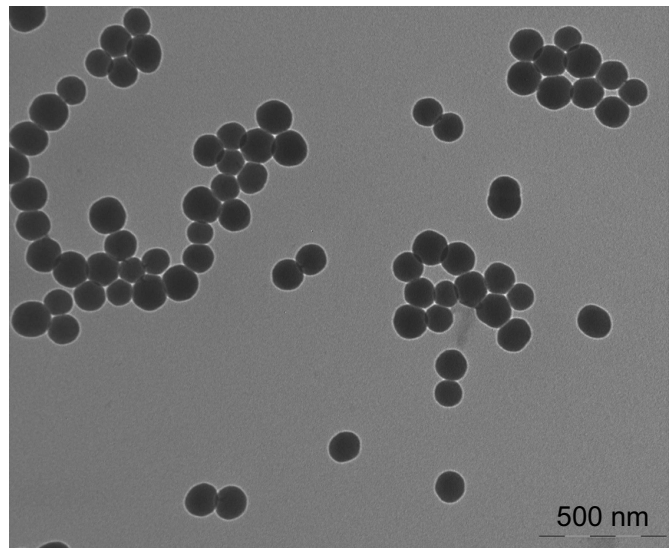

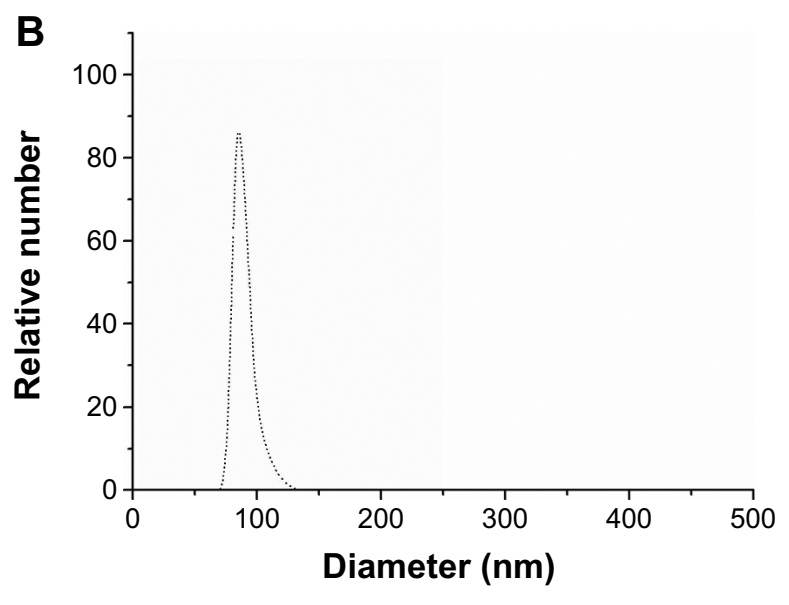

Figure I Transmission electron microscopy photomicrograph (magnification 50,000×) (A) and particle size distribution (B) of the pFDNA-SiO ${ }_{2}-\mathrm{NPs}_{\text {. }}$ Abbreviation: pFDNA-SiO 2 -NPs, Newcastle disease virus $\mathrm{F}$ gene encapsulated in the $\mathrm{SiO}_{2}$ nanoparticles.

A

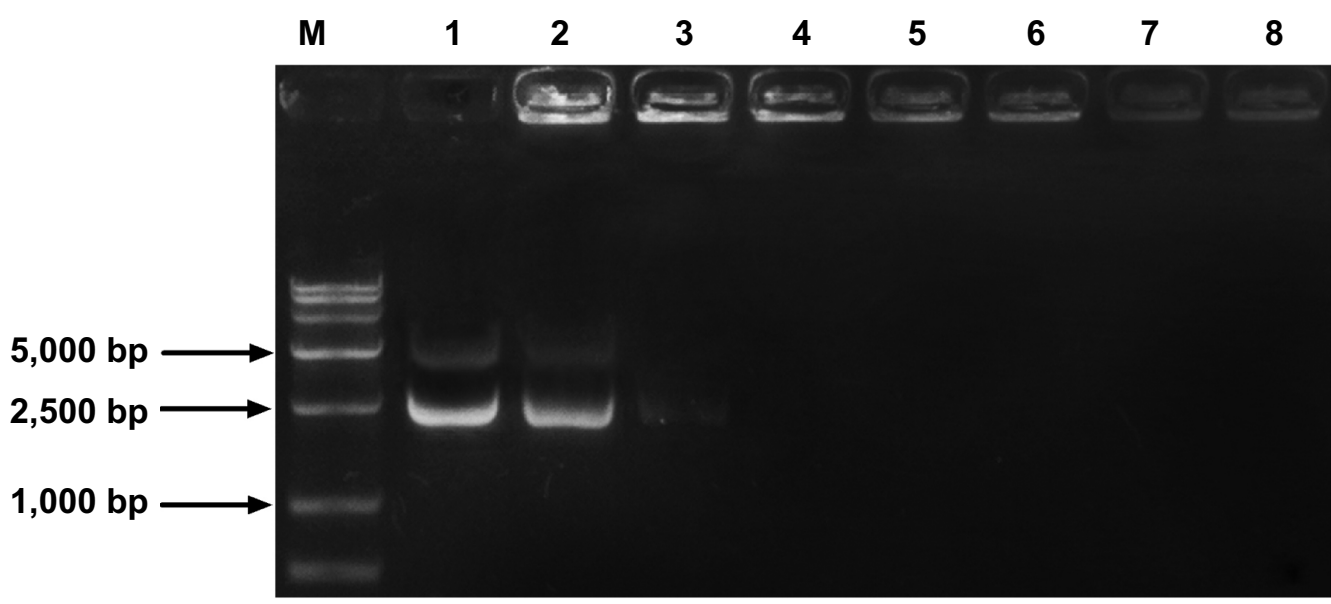

B

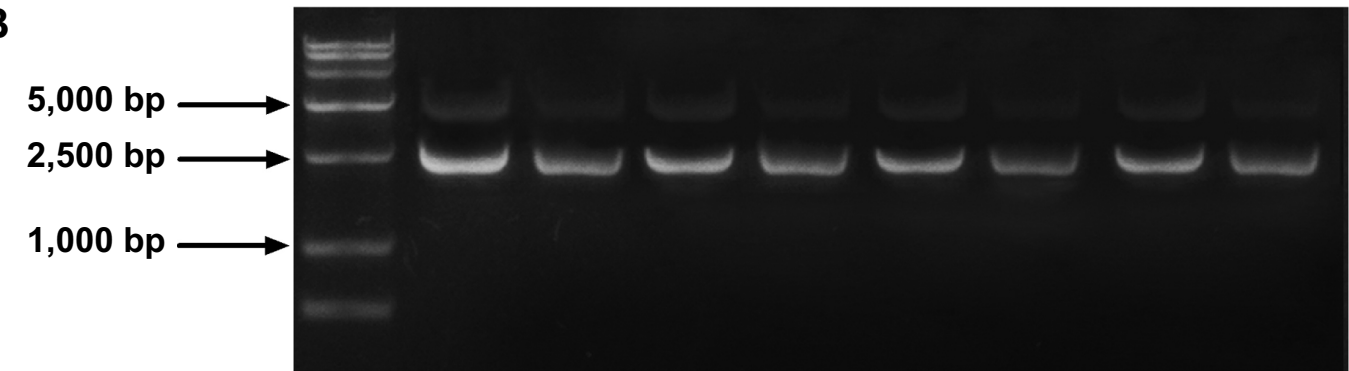

C

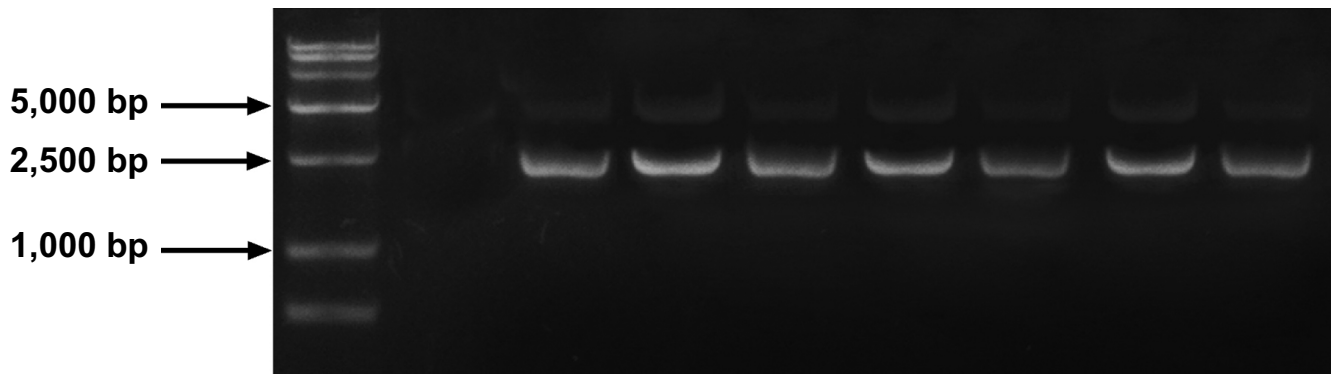

Figure 2 Detection of $\mathrm{SiO}_{2}$ nanoparticles loaded with plasmid DNA for connection, release, and protection properties.

Notes: (A) Agarose gel electrophoresis of the amino-modified silica-DNA complexes. Maker (M): DL I5,000 marker. Lane I: plasmid DNA. Lanes 2-8: the mass ratios of $\mathrm{SiO}_{2}$ to plasmid DNA were I:5, I:I, 5:I, 10:I, 20:I, 30:I, and 40:I, respectively. (B) Stability analysis of the plasmid DNA binding with SiO 2 nanoparticles. (C) Analysis of protection of the plasmid DNA from DNase I digestion. Maker (M): DL 15,000 marker. Lane I: plasmid DNA. Lanes 2-8: the mass ratios of SiO to plasmid DNA were I:5, I:I, 5:I, 10:I, 20:I, 30:I, and 40:I, respectively. 

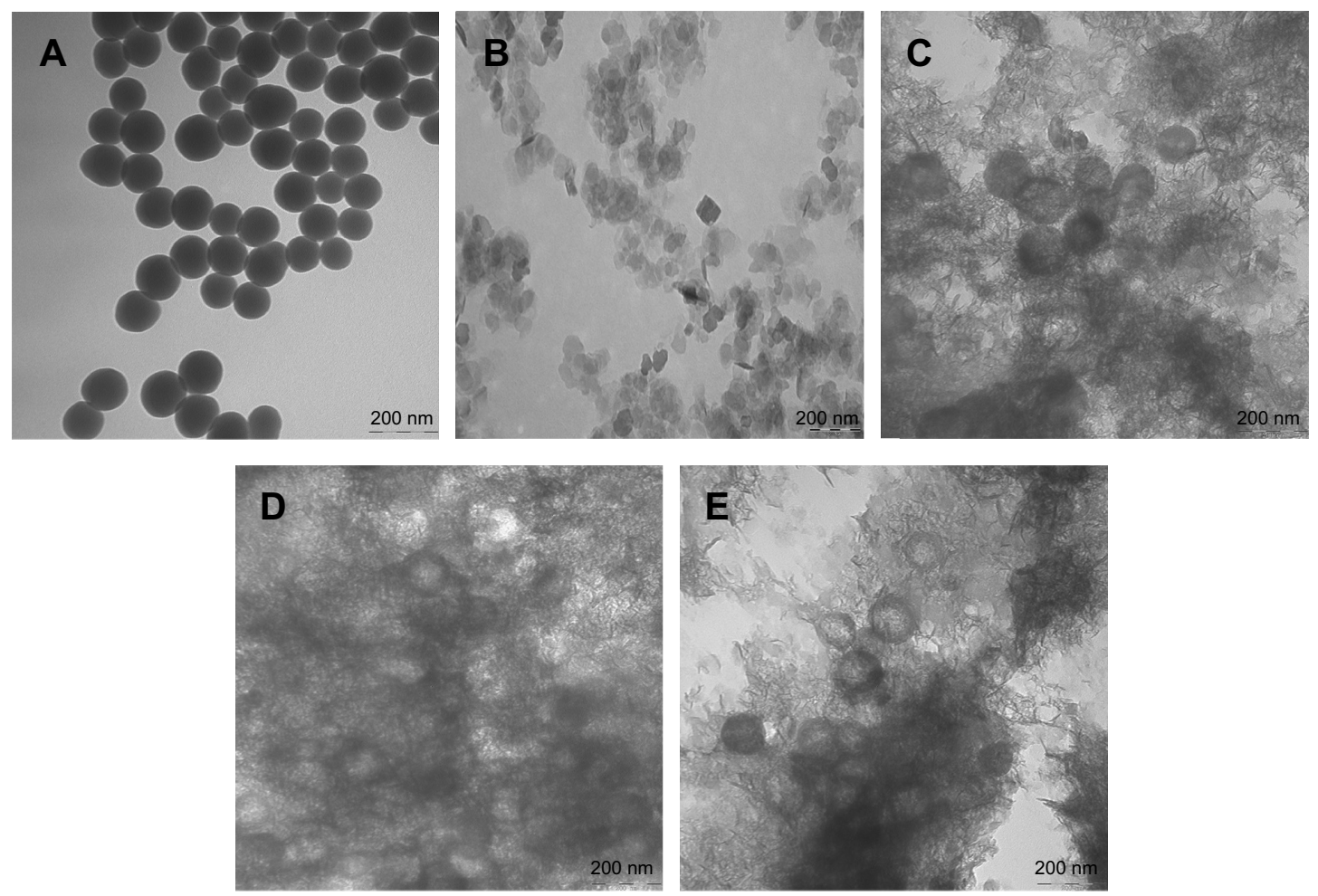

Figure 3 Transmission electron photomicrographs of the pFDNA-SiO ${ }_{2}-\mathrm{NPs}(\mathbf{A}), \mathrm{LDH}(\mathbf{B})$, and pFDNA-LDH@SiO $2-\mathrm{NPs}(\mathbf{C}-\mathbf{E})$. Note: Magnification: 100,000x.

Abbreviations: LDH, layered double hydroxide; NPs, nanoparticles; pFDNA-LDH@SiO 2 -NPs, Newcastle disease virus F gene encapsulated in LDH@SiO $-\mathrm{NPs}$; pFDNA$\mathrm{SiO}_{2}-\mathrm{NPs}$, Newcastle disease virus $\mathrm{F}$ gene encapsulated in the $\mathrm{SiO}_{2}$ nanoparticles.

in a stacking way. The pFDNA-LDH@ $\mathrm{SiO}_{2}$-NPs showed a distribution from 220 to $400 \mathrm{~nm}$ and had an average particle size of $371.93 \mathrm{~nm}$ (Figure 4B). The zeta potentials of LDH and pFDNA-LDH@ $\mathrm{SiO}_{2}$-NPs were +31.47 and +31.63 mV, respectively. Both of these had similarly high zeta potentials, revealing that $\mathrm{LDH}$ does not change the zeta potential of NPs. The LC of the pFDNA-LDH@ $\mathrm{SiO}_{2}$-NPs was calculated to be $39.66 \% \pm 0.45 \%(n=3)$.

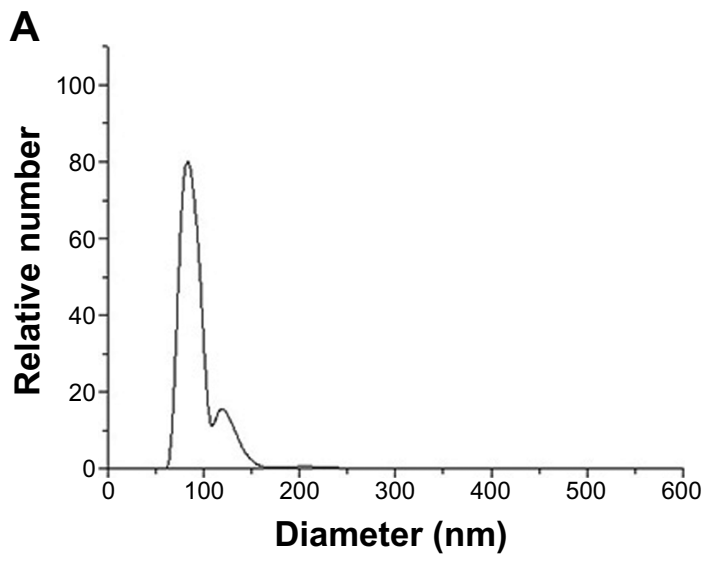

FTIR and XRD analyses of the LDH and pFDNA-LDH@SiO_-NPs

As shown in Figure 5A, compared with the FTIR spectra between the LDH and pFDNA-LDH@ $@ \mathrm{SiO}_{2}-\mathrm{NPs}$, the sharp and strong characteristic bands appeared between $400 \mathrm{~cm}^{-1}$ and $1,000 \mathrm{~cm}^{-1}$, attributed to the $\mathrm{Mg}-\mathrm{O}$ and $\mathrm{Al}-\mathrm{O}$ bonds. The weak peak at $460 \mathrm{~cm}^{-1}$ was attributed to $\mathrm{SiO}_{2} \mathrm{NPs}$, but it was covered by the strong peak of LDH at $450 \mathrm{~cm}^{-1}$, therefore

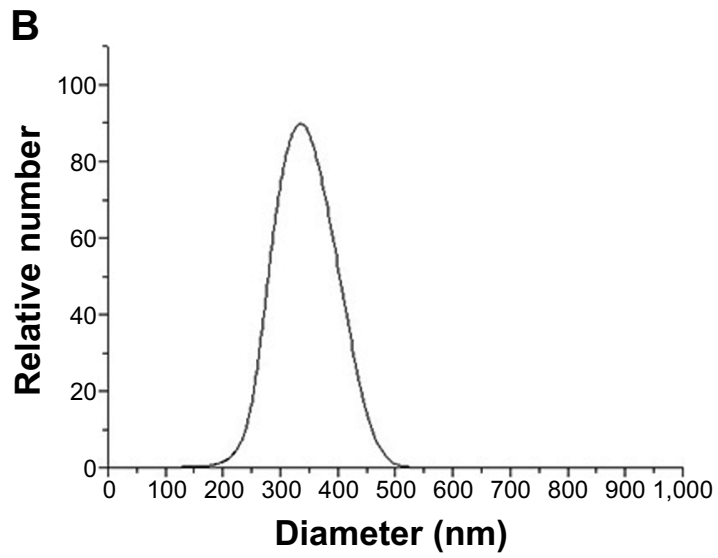

Figure 4 Size distribution of LDH (A) and pFDNA-LDH@SiO - NPs (B).

Notes: Measurement of these particles showed a narrow distribution pattern of LDH and pFDNA-LDH@SiO - NPs, and their average diameters were 99.1 nm and 37 I.93 nm, respectively.

Abbreviations: LDH, layered double hydroxide; NPs, nanoparticles; pFDNA-LDH@SiO $-\mathrm{NPs}$, Newcastle disease virus F gene encapsulated in LDH@SiO $-\mathrm{NPs}$. 
A

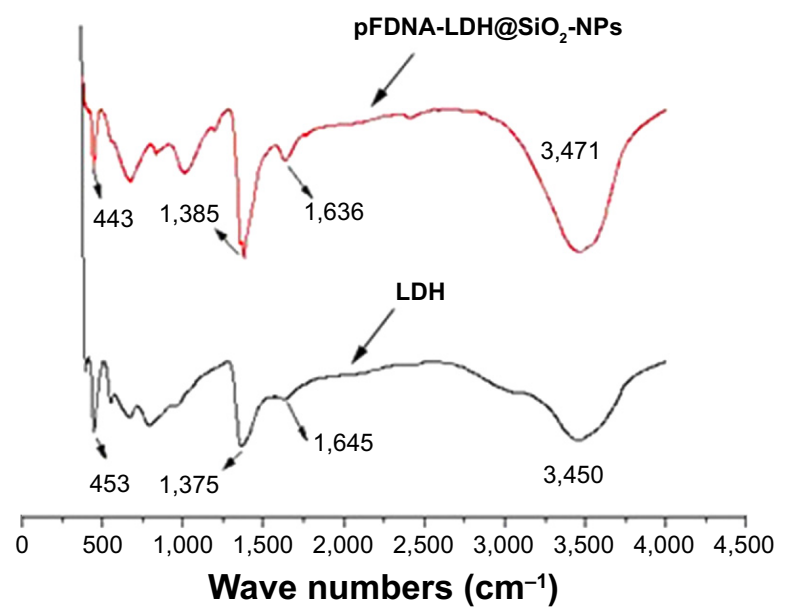

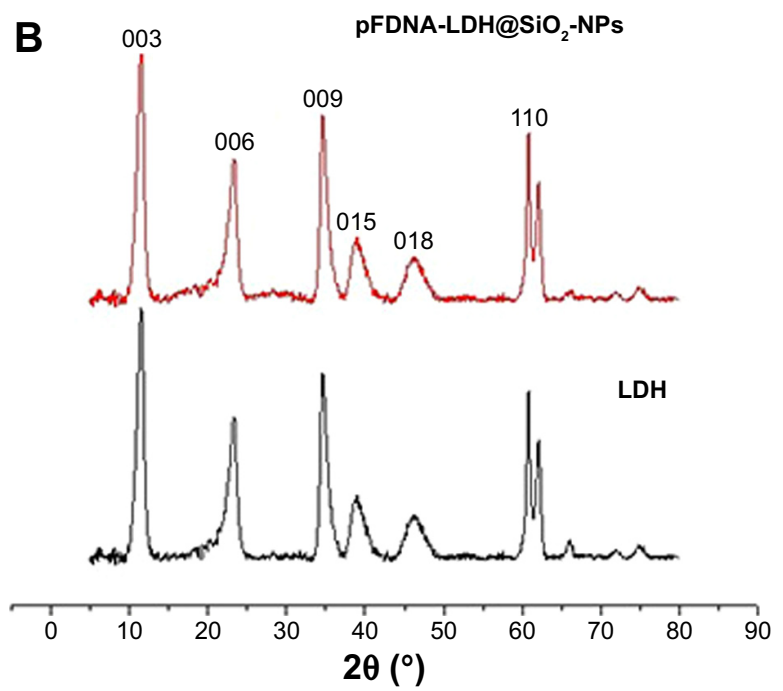

Figure 5 Fourier transform infrared spectroscopy spectrum $(\mathbf{A})$ and XRD curve $(\mathbf{B})$ for each of the LDH and pFDNA-LDH@SiO - -NPs.

Notes: The XRD patterns of the pFDNA-LDH@SiO 2 -NPs exhibited typical diffractions of LDH including (003) and (006), indicative of the presence of LDH crystallite. The characteristic peak at $20^{\circ}$ of pFDNA-LDH@SiO $2-\mathrm{NPs}_{2}$ showed the existence of $\mathrm{SiO}_{2}$.

Abbreviations: LDH, layered double hydroxide; NPs, nanoparticles; $\mathrm{pFDNA}-\mathrm{LDH}_{\mathrm{SiO}}-\mathrm{NPs}$, Newcastle disease virus $\mathrm{F}$ gene encapsulated in LDH@SiO ${ }_{2}-\mathrm{NPs}$; $\mathrm{XRD}, \mathrm{X}$-ray diffraction.

no peak at $460 \mathrm{~cm}^{-1}$ was found in the pFDNA-LDH@ $\mathrm{SiO}_{2}$-NP scanning. The pFDNA-LDH@ $@ \mathrm{SiO}_{2}$-NPs showed an obviously stronger peak, at $1,640 \mathrm{~cm}^{-1}$, than LDH did, because $\mathrm{SiO}_{2} \mathrm{NPs}$ had a strong characteristic band at this wavelength. The weak peaks at $1,640 \mathrm{~cm}^{-1}$ and $1,380 \mathrm{~cm}^{-1}$ are the characteristics of hydroxyl and nitrate ion in the LDH layer, respectively. The results of XRD pattern analysis showed that the $\mathrm{SiO}_{2} @ \mathrm{LDH}-\mathrm{NPs}$ were complexes of LDH crystallite and $\mathrm{SiO}_{2}$ (Figure 5B). The positions of both peaks were generally the same; however, the XRD pattern for pFDNA-LDH@SiO $\mathrm{SiO}_{2}$-NPs showed the characteristic peak at $20^{\circ}$, demonstrating that the appearance of crystal $\mathrm{SiO}_{2}$ and the structure of LDH are not changed after silica coating. Both LDH@SiO $-\mathrm{NPs}$ and LDH displayed the characteristic crystalline peaks, obtaining (003), (006), (009), and (110). The characteristic peak $(015,018)$ was asymmetrical. The XRD patterns of the LDH exhibited the typical diffractions including (003) and (006), indicative of the presence of LDH crystallite. The spike of the characteristic peaks was narrow and sharp, illustrating that the LDH was a single crystalline phase with a high degree of crystallinity.

\section{In vitro release of the pFDNA-LDH@ $\mathrm{SiO}_{2}-\mathrm{NPs}$}

As shown in Figure 6, the amount of DNA released from the pFDNA-LDH@ $\mathrm{SiO}_{2}$-NPs was increased to $47.36 \% \pm 1.95 \%$ $(n=3)$ from 0 to 48 hours, revealing that the burst release mainly takes place during the first 48 hours and is followed by a slow and continuous release, maintained for longer than 96 hours, reaching $64.27 \% \pm 1.52 \%$ but not changing significantly after 96 hours. At 288 hours, the amount of plasmid DNA released from the $\mathrm{pFDNA}-\mathrm{SiO}_{2}-\mathrm{NPs}$ reached $91.36 \% \pm 1.1 \%$.

\section{In vitro expression of the pFDNA- LDH@SiO $-\mathrm{NPs}$}

The pFDNA-LDH@ $\mathrm{SiO}_{2}$-NP group (Figure 7A) and the naked plasmid DNA group (Figure 7B) could be expressed in the cells and the specific fluorescence could be observed. However, no fluorescence signals were observed in the blank LDH@ $\mathrm{SiO}_{2}-\mathrm{NP}$ group (Figure 7C) or the negative cell

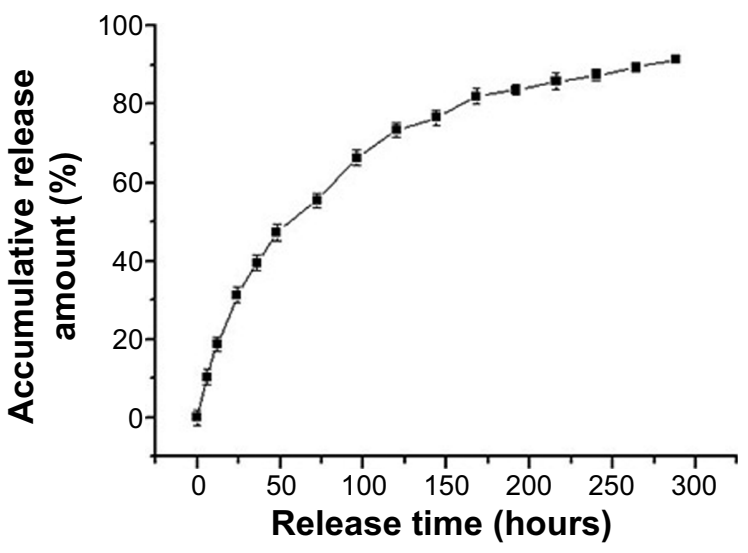

Figure 6 In vitro release profiles of DNA from pFDNA-LDH@SiO ${ }_{2}-\mathrm{NPs}$ in phosphate-buffered saline $(\mathrm{pH} 7.4)$.

Notes: The experiment was repeated three times and measured in triplicate. Data are presented as the mean \pm standard deviation $(n=3)$.

Abbreviations: LDH, layered double hydroxide; NPs, nanoparticles; pFDNA-LDH@ $\mathrm{SiO}_{2}-\mathrm{NPs}$, Newcastle disease virus F gene encapsulated in $\mathrm{LDH} @ S i O_{2}-\mathrm{NPs}$. 
control group (Figure 7D). These results indicate that plasmid DNA can be effectively encapsulated by LDH@ $\mathrm{SiO}_{2}$, and that the plasmid DNA encapsulated in pFDNA-LDH@ $\mathrm{SiO}_{2}$-NPs can be expressed in vitro.

\section{Evaluation of the safety of the pFDNA- LDH@SiO $-\mathrm{NPs}$}

In vitro cytotoxicity of the pFDNA-LDH@SiO ${ }_{2}-\mathrm{NPs}$ The survival rate of chicken embryo kidney cells in the pFDNA-LDH@ $\mathrm{SiO}_{2}$-NP group was $84.12 \% \pm 1.26 \%$, and there were no significant changes in cell morphology as compared with that of the control cells. All the results show that the pFDNA-LDH@ $\mathrm{SiO}_{2}$-NPs cause low cytotoxicity and are very safe for these cells.

\section{Safety of the pFDNA-LDH@SiO 2 -NPs}

Compared with those in the control group, the feeding, water intake, and other behaviors were normal in the chickens immunized IM and IN with the pFDNA-LDH@SiO $\mathrm{Si}_{2}-\mathrm{NPs}$, implying that immunization of the chickens with a high dose of pFDNA-LDH@SiO $\mathrm{Si}_{2}$-NPs is safe. The chickens from the three groups were euthanized, and their duodena, proventriculi, and myocardia were then taken out for pathological section analysis. The results are shown in Figure 8.

\section{Immune efficacy of the pFDNA-LDH@ $\mathrm{SiO}_{2}-\mathrm{NPs}$}

Serum IgG antibody level

Table 1 shows that the serum IgG antibody titers in both the PBS IM and blank LDH@SiO $\mathrm{Si}_{2}$-NPs IM groups were not significantly changed in the 8 weeks (less than $2.0 \log 2$, $P>0.05)$. pFDNA-LDH@ $\mathrm{SiO}_{2}$-NPs administered IN and IM showed lower levels of antibody titers during the first 2 weeks post-immunization, while the antibody titers quickly increased at the 3rd week post-immunization in chickens immunized with the pFDNA-LDH@SiO 2 -NPs IN and IM and peaked at the 5 th week post-immunization. Serum IgG antibody titers in the pFDNA-LDH@ $\mathrm{SiO}_{2}$-NPs IN chickens remained significantly higher $(P<0.01)$ than those in the pFDNA-LDH@SiO - NPs IM and naked plasmid pVAX1-F IM vaccinated chickens until the 8 th week post-immunization, suggesting that the plasmid DNA had a sustained release. All the data show that plasmid DNA can be released slowly from pFDNA-LDH@ $\mathrm{SiO}_{2}$-NPs and specifically stimulates $\mathrm{B}$ lymphocytes to increase serum antibody titers.

\section{IgA antibody level in mucosa extracts}

The changes of IgA antibody levels in serum, bile, tracheal fluid, and Harderian glands post-immunization are shown
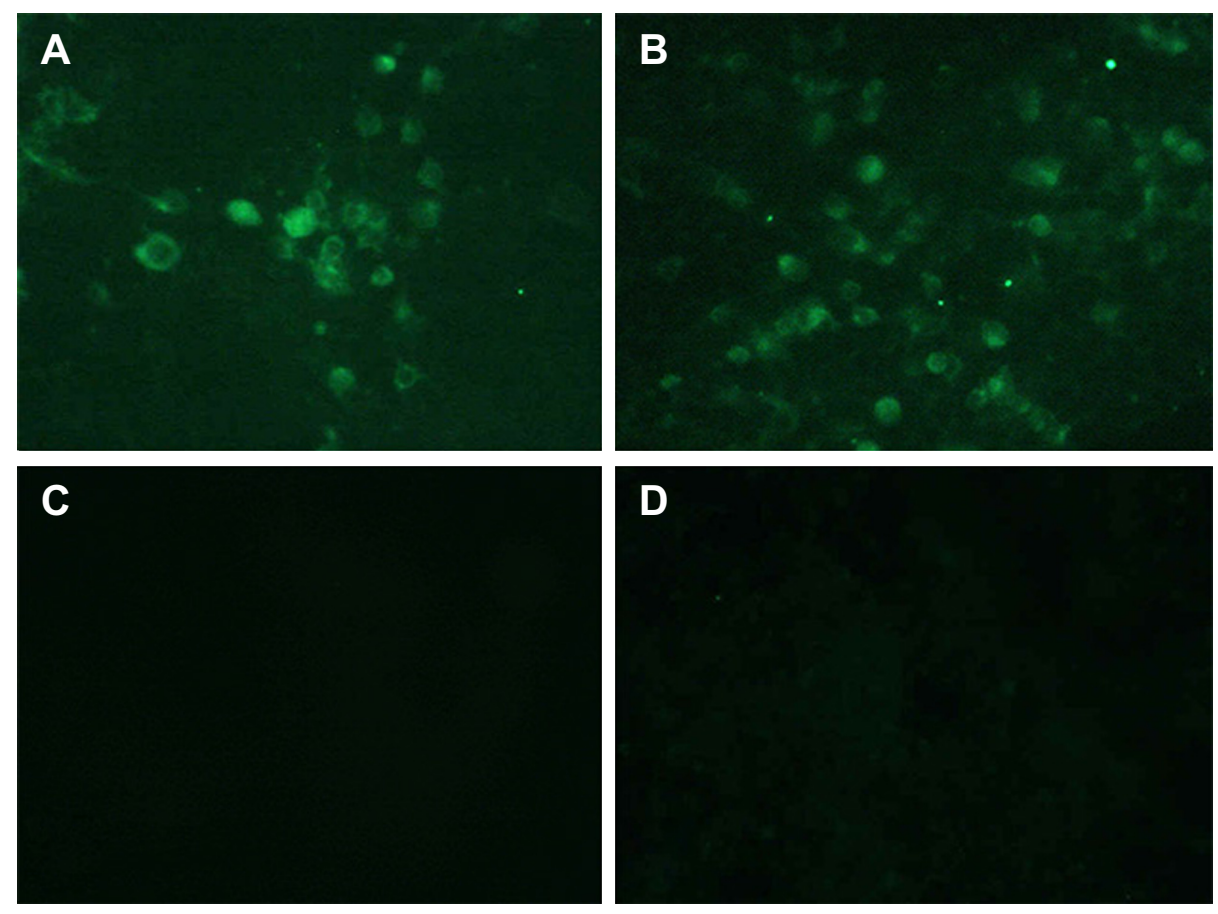

Figure 7 In vitro expression of the pFDNA-LDH@SiO $-\mathrm{NPs}_{2}$ in $293 \mathrm{~T}$ cells assayed by indirect immunofluorescence $(\times 40)$.

Notes: (A) Naked plasmid pVAXI-F(o) DNA group. (B) Transfected pFDNA-LDH@SiO $2-N P s$ group. (C) Blank LDH@SiO - -NPs group. (D) 293 T cell group as the negative control.

Abbreviations: LDH, layered double hydroxide; NPs, nanoparticles; pFDNA-LDH@SiO 2 -NPs, Newcastle disease virus F gene encapsulated in LDH@SiO $-\mathrm{NPs}$. 

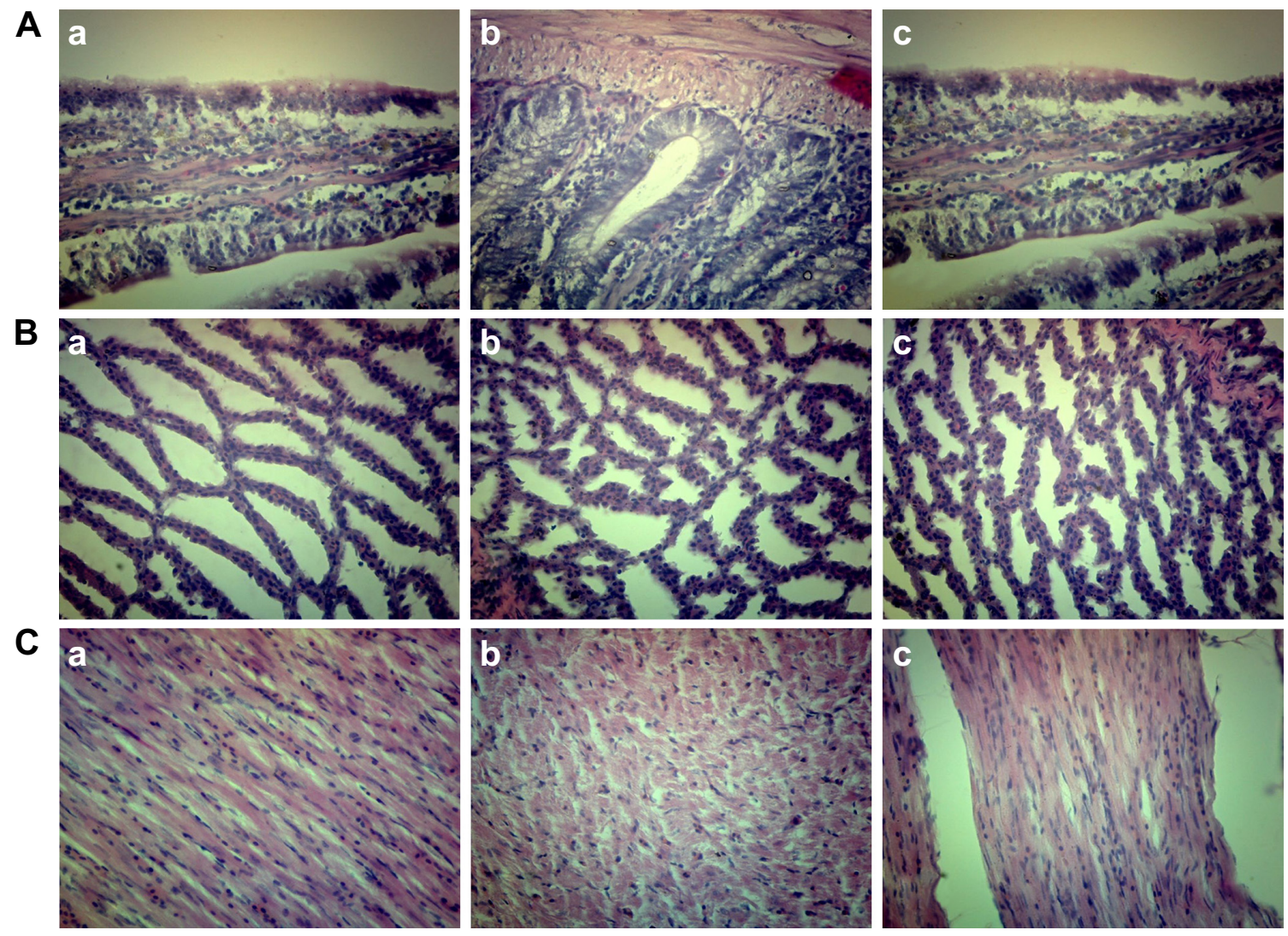

Figure 8 Histopathological analyses of normal duodena, proventriculi, and myocardia.

Notes: (A) Tissues of duodena were immunized with pFDNA-LDH@SiO $-\mathrm{NPs}$ IM (a), pFDNA-LDH@SiO $-\mathrm{NPs}$ IN (b), and PBS IM (c). (B) Tissues of proventriculi were immunized with pFDNA-LDH@SiO $-\mathrm{NPs}_{2} \mathrm{MM}(\mathrm{a}), \mathrm{pFDNA}-\mathrm{LDH} @ \mathrm{SiO}_{2}-\mathrm{NPs}$ IN (b), and PBS IM (c). (C) Tissues of myocardia were immunized with pFDNA-LDH@SiO $-\mathrm{NPs}$ IM (a), pFDNA-LDH@SiO - NPs IN (b), and PBS IM (c).

Abbreviations: IM, intramuscularly; IN, intranasally; LDH, layered double hydroxide; NPs, nanoparticles; PBS, phosphate-buffered saline; pFDNA-LDH@SiO - -NPs,

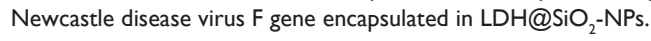

in Figure 9. The IgA antibody levels in the pFDNA-LDH@, $\mathrm{SiO}_{2}$-NPs IN, pFDNA-LDH@SiO_-NPs IM and naked plasmid DNA IM groups were significantly higher than those in the blankLDH@SiO 2 -NPs IM and PBS IM groups $(P<0.01)$. The chickens immunized with the pFDNA-LDH@ $\mathrm{SiO}_{2}-\mathrm{NPs}$ IN had significantly higher IgA antibody titers $(P<0.01)$ and longer period of IgA antibody secretion in serum (Figure 9A), tracheal fluid (Figure 9B), bile (Figure 9C), and Harderian glands (Figure 9D) than the chickens of other groups. The IgA antibody titers in the pFDNA-LDH@SiO $-\mathrm{SPs}_{2} \mathrm{IM}$ group were significantly higher and their secretion period longer than in the naked plasmid DNA IM group $(P<0.05)$. It can be clearly observed that pFDNA-LDH@ $\mathrm{SiO}_{2}-\mathrm{NPs}$ were able to induce quicker and better mucosal immune responses than the naked plasmid DNA vaccine.

\section{Lymphocyte proliferation assay}

As shown in Table 2, there were no significant differences between chickens immunized with the pFDNA-LDH@ $\mathrm{SiO}_{2}-\mathrm{NPs}$ IN or IM and chickens immunized with the naked plasmid pVAX1-F(o) DNA IM at the 3rd week postimmunization $(P>0.05)$. The chickens immunized with the pFDNA-LDH@SiO 2 -NPs IN had significantly higher SI than chickens immunized with the pFDNA-LDH@ $\mathrm{SiO}_{2}-\mathrm{NPs}$ IM and the naked plasmid pVAX1-F(o) DNA IM $(P<0.05)$ at the 4th week post-immunization; the higher SI was maintained until the 6th week post-immunization $(P<0.05)$. It was clear that the pFDNA-LDH@ $@ \mathrm{SiO}_{2}-\mathrm{NPs}_{\mathrm{N}}$ significantly enhanced the immune function of $\mathrm{T}$ lymphocytes in the immunized chickens.

\section{Protection against the infection of NDV strain $\mathrm{F}_{48} \mathrm{E}_{9}$} Within 2-5 days, the highly virulent NDV strain $\mathrm{F}_{48} \mathrm{E}_{9}$ had killed all the chickens treated with either PBS IM or blank LDH@ $\mathrm{SiO}_{2}$-NPs IM (Table 3). In contrast, strain $\mathrm{F}_{48} \mathrm{E}_{9}$ killed only $60 \%, 40 \%$, and $0 \%$ of the chickens treated with the naked plasmid pVAX1-F(o)DNA IM, pFDNA-LDH@, $\mathrm{SiO}_{2}$-NPs IM, and pFDNA-LDH@ $\mathrm{SiO}_{2}-\mathrm{NPs}$ IN, respectively (Table 3). Two chickens of the pFDNA-LDH@ $\mathrm{SiO}_{2}-\mathrm{NPs}$ IM group died, and the protective efficacy was $60 \%$. There were 


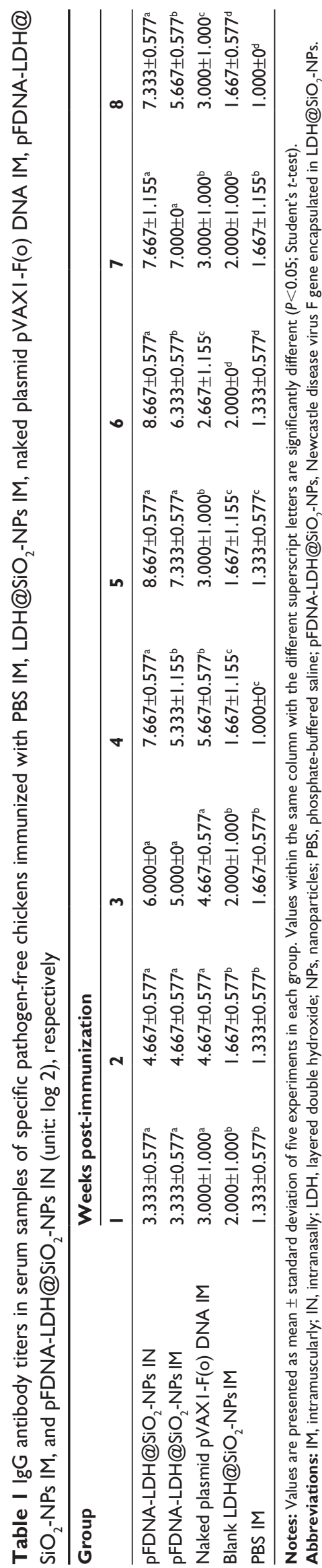

no clinical signs in chickens immunized with the pFDNALDH@SiO $\mathrm{SiO}_{2}$-NPs IN after being challenged with the strain $\mathrm{F}_{48} \mathrm{E}_{9}$, and no pathological and histopathological changes were found in their duodena (Figure 10A) and myocardia (Figure 10B).

The dead chickens from the pFDNA-LDH@SiO $\mathrm{Si}_{2}-\mathrm{NPs}$ IM, naked plasmid pVAX1-F(o) DNA IM, or PBS IM groups had the typical pathological changes of ND, such as mucosal hemorrhages in proventriculus papillae, heart fat, duodena, and whole intestines. Much serious hemorrhaging on the mucous layer of duodena was found through examination of the histopathology slide (Figure 10C). Other pathological changes such as incomplete intestinal wall and intestinal villus and follicular cell necrosis were seen (Figure 10D). Together, these findings show that the pFDNA-LDH@ $\mathrm{SiO}_{2}$-NPs IN quickly induced an effective mucosal immune response and protected chickens against NDV infection.

\section{Discussion}

NDV infection is still one of the infectious avian diseases worldwide with serious long-term morbidities and mortalities. Currently, the effective strategies for prevention and control of NDV infection are still limited. However, DNAbased vaccines have emerged as a new kind of vaccine and have shown promising potential against NDV infection.

Like most vaccines, NDV vaccines do not prevent the vaccinated animals from becoming infected with a virulent NDV and subsequently shedding the virus, ${ }^{40}$ but the amount of virus shed in the feces of vaccinated animals was lower than that of non-vaccinated birds. ${ }^{41}$ Current measures for the control of ND primarily depend on flock vaccination and culling of infected or suspected infected birds. Although current vaccines can protect infected birds, virus replication and shedding may still happen, albeit at a reduced level. ${ }^{42}$

Various approaches have been applied to improve the systemic immune response to infectious bacteria or viruses. Among them, DNA vaccination has been demonstrated to be one effective way to elicit protective immunity against pathogens. DNA vaccines that mimic live attenuated vaccines in their ability to induce both humoral and cellular immune responses may prove to be a useful alternative. ${ }^{43}$ The potential for DNA vaccines to overcome maternal immunity, stability issues, costs, and the non-requirement of cold chain has highlighted the promise of DNA vaccines. Here, we have developed an NDV-specific DNA NP vaccine and shown that it is better than a naked DNA vaccine. It is able to protect plasmid DNA from degradation by 
A
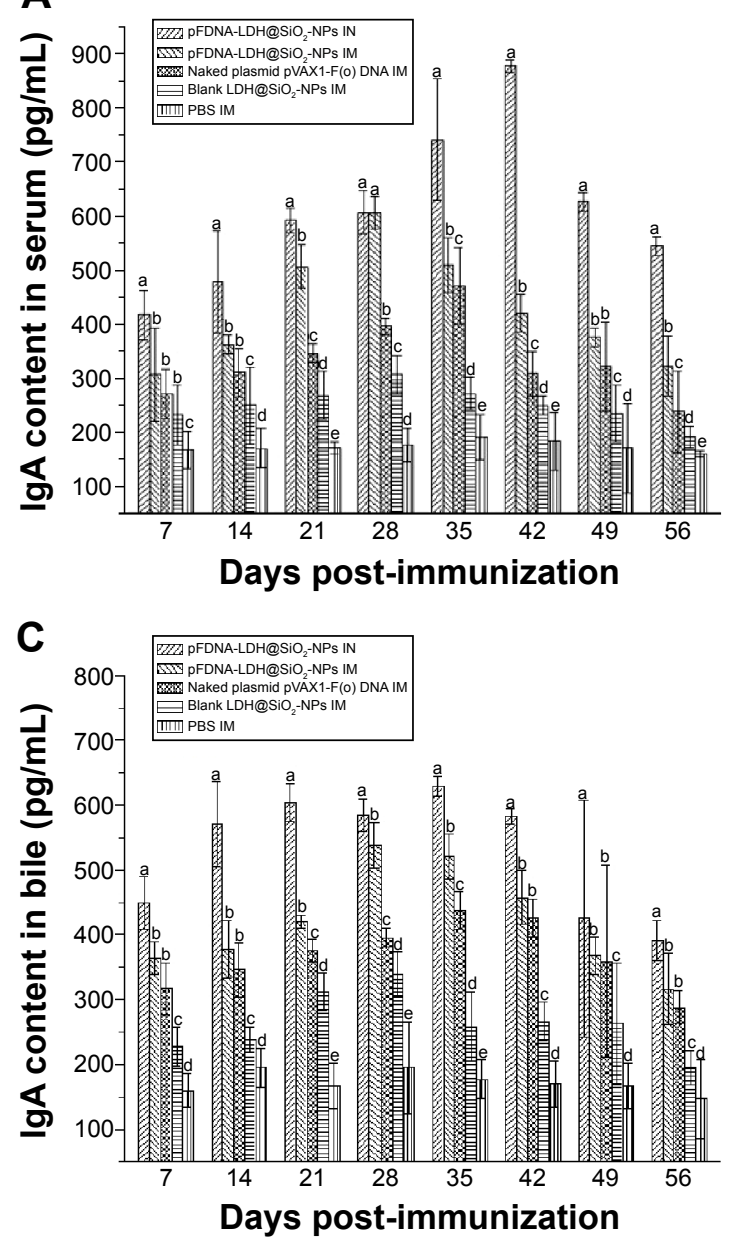

B
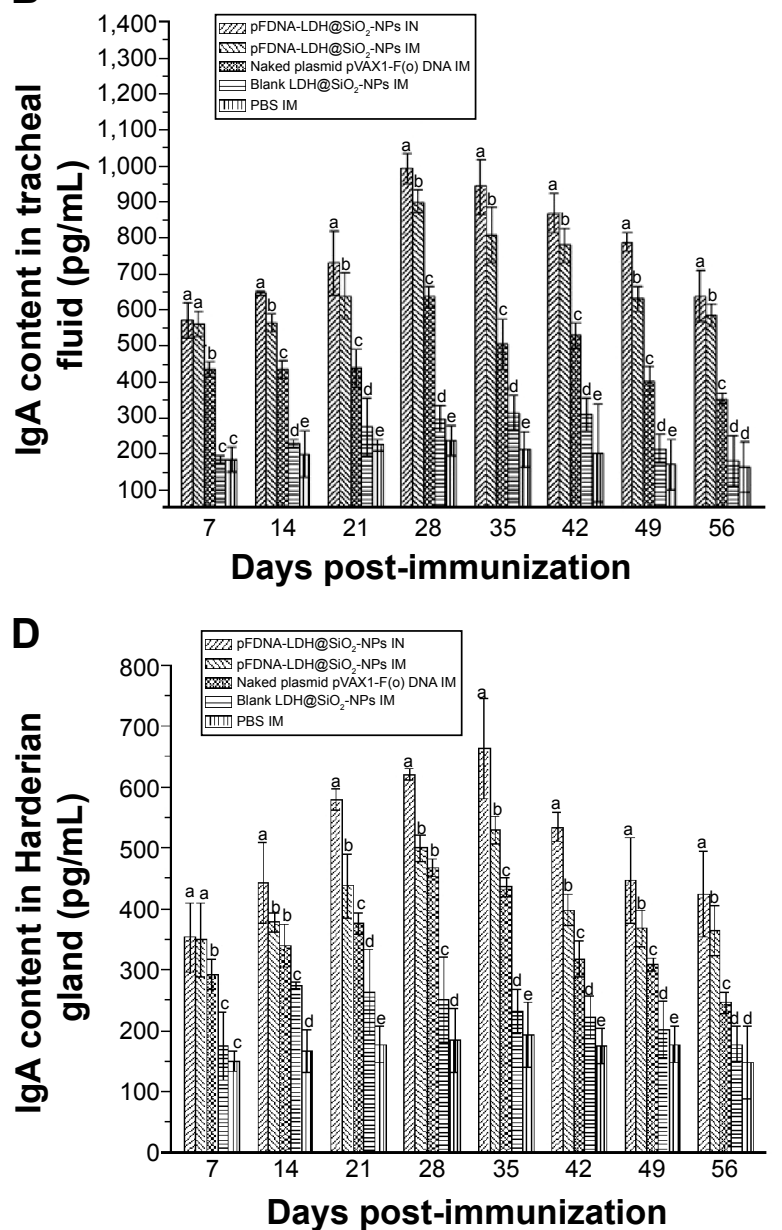

Figure 9 IgA antibody levels in serum (A), tracheal fluid (B), bile (C), and Harderian glands (D) of specific pathogen-free chickens immunized with PBS IM, blank LDH@ $\mathrm{SiO}_{2}$-NPs IM, naked plasmid pVAXI-F(o) DNA IM, pFDNA-LDH@SiO $-N P s$ IM, and pFDNA-LDH@SiO $-N P s ~ I N$.

Notes: IgA antibody levels are presented as mean \pm standard deviation of five experiments. Data with different small letters show significant difference $(P<0.05)$.

Abbreviations: IM, intramuscularly; IN, intranasally; LDH, layered double hydroxide; NPs, nanoparticles; PBS, phosphate-buffered saline; pFDNA-LDH@SiO,-NPs,

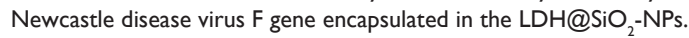

DNase and allows the plasmid DNA to be expressed and thus enhance the mucosal immune response and antibody immune responses.

Nowadays, many NP carriers such as microemulsions, liposomes, inorganic NPs, virosomes, virus-like particles, and polymeric microparticles have been applied in vaccinology. ${ }^{44}$ Due to the similarity of their size to that of a pathogen, these particles can be taken up by antigen-presenting cells $\mathrm{s}^{45,46}$ and thus enter living cells. Therefore, delivery systems play a major role in enhancing antigen processing and stimulating immunity. Zhao et al previously reported that the F gene of NDV in plasmid DNA encapsulated in

Table 2 The stimulation index of T lymphocyte proliferation in specific pathogen-free chickens post-immunization

\begin{tabular}{|c|c|c|c|c|c|c|}
\hline \multirow[t]{2}{*}{ Group } & \multicolumn{6}{|c|}{ Stimulation index } \\
\hline & $\begin{array}{l}7 \text { days post- } \\
\text { immunization }\end{array}$ & $\begin{array}{l}\text { I4 days post- } \\
\text { immunization }\end{array}$ & $\begin{array}{l}\text { 2I days post- } \\
\text { immunization }\end{array}$ & $\begin{array}{l}28 \text { days post- } \\
\text { immunization }\end{array}$ & $\begin{array}{l}35 \text { days post- } \\
\text { immunization }\end{array}$ & $\begin{array}{l}42 \text { days post- } \\
\text { immunization }\end{array}$ \\
\hline pFDNA-LDH@SiO,-NPs IN & $0.522 \pm 0.02 \mathrm{I}^{\mathrm{a}}$ & $0.689 \pm 0.029^{a}$ & $1.110 \pm 0.019^{a}$ & $1.444 \pm 0.039^{\mathrm{a}}$ & $1.866 \pm 0.07^{a}$ & $2.056 \pm 0.042^{\mathrm{a}}$ \\
\hline pFDNA-LDH@SiO & $0.517 \pm 0.003^{\mathrm{a}}$ & $0.690 \pm 0.014^{\mathrm{a}}$ & I. $104 \pm 0.028^{a}$ & $\mathrm{I} .234 \pm 0.07 \mathrm{I}^{\mathrm{b}}$ & $1.745 \pm 0.096^{b}$ & $1.803 \pm 0.028^{b}$ \\
\hline Naked plasmid pVAXI-F(o) DNA IM & $0.5|5 \pm 0.03|^{\mathrm{a}}$ & $0.67 I \pm 0.017^{\mathrm{a}}$ & $1.009 \pm 0.007^{\mathrm{a}}$ & $1.228 \pm 0.057^{\mathrm{b}}$ & $1.566 \pm 0.037^{c}$ & $1.606 \pm 0.025^{c}$ \\
\hline Blank LDH@SiO & $0.402 \pm 0.007^{b}$ & $0.478 \pm 0.004^{\mathrm{b}}$ & $0.727 \pm 0.075^{c}$ & $0.805 \pm 0.047^{c}$ & $\mathrm{I} .12 \mathrm{I} \pm 0.28 \mathrm{I}^{\mathrm{d}}$ & $1.044 \pm 0.055^{d}$ \\
\hline PBSIM & $0.364 \pm 0.03^{\mathrm{b}}$ & $0.44 I \pm 0.030^{b}$ & $0.70 I \pm 0.056^{c}$ & $0.743 \pm 0.028^{d}$ & $1.100 \pm 0.02 \mathrm{I}^{\mathrm{d}}$ & $1.008 \pm 0.023^{\mathrm{d}}$ \\
\hline
\end{tabular}

Notes: Values are presented as mean \pm standard deviation of five experiments in each group. Values within the same column with the different superscript letters are significantly different $(P<0.05$; Student's $t$-test).

Abbreviations: IM, intramuscularly; IN, intranasally; LDH, layered double hydroxide; NPs, nanoparticles; PBS, phosphate-buffered saline; pFDNA-LDH@SiO - -NPs,

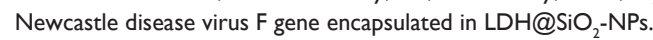


Table 3 Protection of the immunized specific pathogen-free chickens after being challenged with the highly virulent Newcastle disease virus strain $\mathrm{F}_{48} \mathrm{E}_{9}$

\begin{tabular}{|c|c|c|c|}
\hline Treatment & $\begin{array}{l}\text { Number of dead } \\
\text { chickens/total number } \\
\text { of chickens }\end{array}$ & Mortality (\%) & Protection (\%) \\
\hline PBS IM & $5 / 5$ & 100 & 0 \\
\hline Blank LDH@SiO $-\mathrm{NPs}$ IM & $5 / 5$ & 100 & 0 \\
\hline Naked plasmid pVAXI-F(o) DNA IM & $3 / 5$ & 60 & 40 \\
\hline pFDNA-LDH@SiO & $2 / 5$ & 40 & 60 \\
\hline pFDNA-LDH@SiO,-NPs IN & $0 / 5$ & 0 & 100 \\
\hline
\end{tabular}

Abbreviations: IM, intramuscularly; IN, intranasally; LDH, layered double hydroxide; NPs, nanoparticles; PBS, phosphate-buffered saline; pFDNA-LDH@SiO 2 -NPs, Newcastle disease virus $\mathrm{F}$ gene encapsulated in $\mathrm{LDH}_{\mathrm{S}} \mathrm{SiO}_{2}$-NPs.

chitosan ${ }^{36}$ or PLGA ${ }^{47}$ NPs could be stabilized and sustainably released from the plasmid DNA and induced stronger mucosal immune responses than non-encapsulated plasmid DNA. In recent years, the shell-core nanocomposite has been developed as a new type of composite material and is a hot topic of current research. ${ }^{48,49}$ In order to apply the biodegradable NPs as a delivery vector for veterinary virus vaccines, in this study, we determined whether biodegradable NPs can be used to deliver newly developed DNA vaccines. LDH@ $\mathrm{SiO}_{2}$ shell-core nanocomposite was first synthesized as a carrier for the $\mathrm{F}$ gene plasmid DNA of NDV delivery systems. The plasmid DNA carrying the F gene of NDV was then encapsulated into the LDH@ $\mathrm{SiO}_{2}-$ NPs by a complex coacervation method. The advantages of pFDNA-LDH@ $\mathrm{SiO}_{2}$-NPs prepared using a complex coprecipitation method include mild preparation condition, protection of plasmid DNA from degradation, remaining solvent in the course of NP preparation, and ease of obtaining
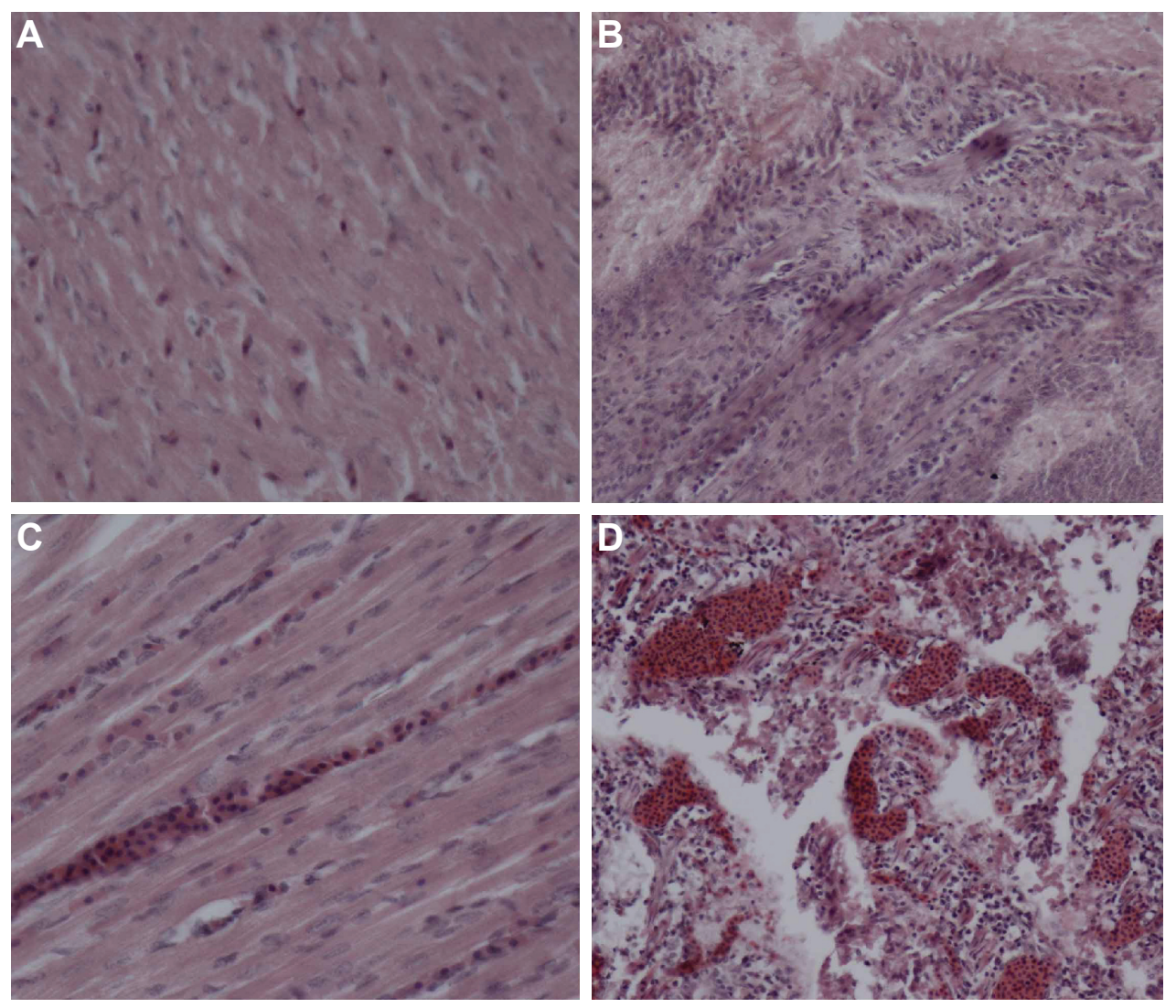

Figure 10 Histopathological analyses of the duodena and myocardia of chickens challenged with the highly virulent NDV strain $\mathrm{F}_{48} \mathrm{E}_{9}$.

Notes: (A) Tissues of the duodena from chickens immunized with pFDNA-LDH@SiO - NPs IN. (B) Tissues of the myocardia from chickens immunized with pFDNA-LDH@ $\mathrm{SiO}_{2}-\mathrm{NPs}$ IN. (C) Tissues of the duodena from chickens immunized with pFDNA-LDH@SiO $-\mathrm{NPs}$ IM, naked plasmid pVAXI-F(o) DNA IM, or PBS IM. (D) Tissues of the myocardia from chickens in groups immunized with the pFDNA-LDH@SiO - -NPs IM, naked plasmid pVAXI-F(o) DNA IM, or PBS IM.

Abbreviations: IM, intramuscularly; IN, intranasally; LDH, layered double hydroxide; NDV, Newcastle disease virus; NPs, nanoparticles; PBS, phosphate-buffered saline; pFDNA-LDH@SiO $-\mathrm{NPs}$, NDV F gene encapsulated in the $\mathrm{LDH}_{2} @ \mathrm{SiO}_{2}-\mathrm{NPs}$. 
high-quality $\mathrm{SiO}_{2}$ NPs. The NPs that had the desired size and retained the bioactivity of the loaded plasmid DNA were produced under the optimal preparation conditions. The average sizes of the pFDNA-SiO $-\mathrm{NPs}, \mathrm{LDH}$, and pFDNA-LDH@SiO 2 -NPs were 90.5, 99.1, and 371.93 nm, respectively, and the zeta potentials were $+1.43,+31.47$, and $+31.63 \mathrm{mV}$, respectively. $\mathrm{LDH} @ \mathrm{SiO}_{2}-\mathrm{NPs}$ were demonstrated to be able to bind and protect the plasmid DNA by DNA protection assays. LC for incorporating DNA into NPs is an important parameter, because it determines both the effectiveness of the gene delivery and subsequent expression levels of encoded genes in vitro and in vivo. ${ }^{50}$ In this study, the prepared pFDNA-LDH@ $\mathrm{SiO}_{2}-\mathrm{NPs}$ showed a large surface area with an LC of $39.66 \% \pm 0.45 \%$. These results show that the prepared pFDNA-LDH@,SiO $-\mathrm{NPs}_{2}$ have the potential to serve as a DNA vaccine delivery system.

The FTIR and XRD analyses of pFDNA-LDH@ $@ \mathrm{SiO}_{2}-$ NPs showed that LDH and pFDNA-LDH@SiO 2 -NPs had an obvious absorption peak and that the synthesized LDH had a simple crystal phase and high crystallinity.

It was reported previously that the swelling of the NPs and $\mathrm{pH}$ values of the released medium may influence the release profile of the gene from NPs. ${ }^{51}$ Hence, the release analysis study was conducted by incubating pFDNA-LDH@, $\mathrm{SiO}_{2}$-NPs in PBS ( $\mathrm{pH}$ 7.4) and the cumulatively released amounts were monitored at different time intervals. Figure 7 shows that the plasmid DNA could be released slowly from the pFDNA-LDH@SiO_-NPs. These results indicate that the LDH@ $\mathrm{SiO}_{2}-\mathrm{NPs}$ can be used as a controlled release carrier, prolonging the expression duration of the genes within the body.

We showed that the expression of NDV-specific antigen, $\mathrm{F}$ gene, was detected in vitro transfected assay. In the meantime, the in vitro cytotoxicity studies also showed that the pFDNA-LDH@SiO $-\mathrm{NPs}$ had low cytotoxicity and high safety. In vivo safety tests showed that the pFDNA-LDH@ $@ \mathrm{SiO}_{2}-\mathrm{NPs}$ were safe for use either IN or IM and no pathological changes were observed in the immunized chickens. These findings show that the production procedures of NPs are safe and that LDH@ $\mathrm{SiO}_{2}$-NPs can retain the bioactivity of plasmid DNA.

A previous report showed that the main factor eliciting mucosal immune response for effective mucosal vaccines is the quick and strong release of a specific secretory IgA (sIgA).$^{52}$ This is particularly critical for prevention of ND because the transmission routes of NDV are mainly the respiratory and digestive tracts. The nasal mucosa is the first portal of entry for the inhaled antigens, which can lead to both efficient mucosal and systemic immune responses. ${ }^{53}$ Intranasal immunization is a very effective way of eliciting mucosal and systemic immune responses. ${ }^{54,55}$ Therefore, the ability of LDH@ $\mathrm{SiO}_{2}-\mathrm{NPs}$ to elicit a mucosal immune response was investigated. Our results revealed that pFDNA-LDH@ $\mathrm{SiO}_{2}-$ NPs given IN induced stronger mucosal immune responses and a more sustained release of plasmid DNA than the naked plasmid DNA. Furthermore, the IgA antibody levels in the pFDNA-LDH@SiO_-NPs IN chickens were much higher than in our previously reported results $(P<0.05) .^{36,47}$

The LDH@SiO -coupled NDV DNA vaccines could also induce a humoral immune response which lasts for a longer period of time. Our results showed that a high level of IgG antibody titers was detected in chickens given pFDNALDH@ $\mathrm{SiO}_{2}-\mathrm{NPs}$ IN. The cellular immune response is essential for virus clearance ${ }^{56}$ even though the specific cellular immunity is not sufficient by itself to protect against virulent NDV. ${ }^{57}$ Lymphocyte homeostasis is required for the maintenance of normal immune function. In our study, lymphocyte proliferation assay showed that the chickens immunized IN with the pFDNA-LDH@ $\mathrm{SiO}_{2}-\mathrm{NPs}_{\mathrm{S}}$ had a significantly higher $\mathrm{SI}$ than the chickens in other groups $(P<0.05)$. These results clearly demonstrate that the pFDNA-LDH@ $\mathrm{SiO}_{2}-\mathrm{NPs}$ significantly enhanced the immune function of $\mathrm{T}$ lymphocytes in the immunized chickens.

In summary, intranasal immunization of SPF chickens with the pFDNA-LDH@SiO_-NPs induced stronger cellular, humoral, and mucosal immune responses and achieved a sustained release effect. Additionally, neither clinical signs nor mortality were observed in chickens immunized IN with the pFDNA-LDH@SiO $\mathrm{SiO}_{2}-\mathrm{NPs}$. After being challenged with the virulent strain $\mathrm{F}_{48} \mathrm{E}_{9}$, the protective efficacy of pFDNALDH@ $\mathrm{SiO}_{2}$-NPs was as high as $100 \%$.

This work has laid a good foundation for using LDH@ $\mathrm{SiO}_{2}$-NPs with a shell-core structure as a delivery carrier in mucosal immunization for vaccines. In addition, this study has also shown that LDH@ $\mathrm{SiO}_{2}-\mathrm{NPs}$ can be a promising technology for needle-free vaccination with great application potential. However, despite its favorable bioavailability, biodegradable nature, and long-term antigen release profile, a successful LDH@ $\mathrm{SiO}_{2}$-encapsulated vaccine is yet to be developed and introduced for use in both animals and humans. Currently, the NPs used in the field of DNA vaccine delivery are still at an early stage of their development. A lot of challenges remain, such as a lack of understanding of how the physiochemical properties of NPs affect the targeted delivery of plasmid DNA and how the surface charge and additional targeting may influence the uptake of vaccines, and the cost of preparing these NPs must be reduced. 
We believe that, with the development of technologies in biomedical and material sciences, these challenges can be eventually resolved in the future, and that $\mathrm{LDH} @ \mathrm{SiO}_{2}-\mathrm{NPs}$ with a shell-core structure will be widely applied as delivery carriers in the fields of vaccine antigens and biomedicine.

\section{Conclusion}

In this study, the biodegradable $\mathrm{LDH} @ \mathrm{SiO}_{2}-\mathrm{NPs}$ were prepared in order to find effective vaccine delivery systems and immunostimulants. In vitro cellular experiments showed that LDH@ $\mathrm{SiO}_{2}$-NPs with a shell-core structure as a delivery carrier for NDV DNA vaccine not only protected the plasmid DNA from degradation, but also exhibited high transfection efficiency. Animal experiments showed that intranasal immunization of SPF chickens with pFDNA$\mathrm{LDH} @ \mathrm{SiO}_{2}$-NPs caused much stronger cellular, humoral, and mucosal immune responses and achieved the sustained release effect than the pFDNA-LDH@ $\mathrm{SiO}_{2}-\mathrm{NPs} \mathrm{IM}$, naked plasmid pVAX1-F (o) DNA, and blank LDH@SiO 2 -NPs. Further, immunization with pFDNA-LDH@ $\mathrm{SiO}_{2}-\mathrm{NPs}$ also induced significantly efficient $\mathrm{T}$-cell proliferation. Our results indicate that $\mathrm{LDH} @ \mathrm{SiO}_{2}-\mathrm{NPs}$ can serve as a promising DNA vaccine delivery carrier for needle-free vaccination and have great application potential.

\section{Acknowledgments}

We gratefully acknowledge the Key Laboratory of Functional Inorganic Material Chemistry (Heilongjiang University), the Ministry of Education and Engineering Research Center of Agricultural Microbiology Technology, and the Ministry of Education for providing the facilities to carry out this work. This work was supported in part by the National Natural Science Foundation of China (31072119), the Key Project of the Chinese Ministry of Education (212048), the Key Program of Natural Science Foundation of Heilongjiang Province of China (ZD201515), the Innovative Research Team for Agricultural Microbiology Fermentation Technology at Heilongjiang Provincial University (2012td009), the Changjiang Scholar Candidates Program for Provincial Universities in Heilongjiang (2014CJHB005), the Scientific and Technological Key Project of Heilongjiang Province (GC13B403), the Early Research and Development Cultivation Project of Scientific and Technological Achievements Industrialization for Provincial Universities in Heilongjiang (1253CGZH10), and the Technological Innovation Talent Foundation of Harbin (2013RFQXJ030).

\section{Disclosure}

The authors report no conflicts of interest in this work.

\section{References}

1. Sinkovics JG, Horvath JC. Newcastle disease virus (NDV): brief history of its oncolytic strains. J Clin Virol. 2000;16(1):1-15.

2. Alexander DJ, Aldous EW, Fuller CM. The long view: a selective review of 40 years of Newcastle disease research. Avian Pathol. 2012; 41(4):329-335.

3. Tseng LP, Chiou CJ, Deng MC, et al. Evaluation of encapsulated Newcastle disease virus liposomes using various phospholipids administered to improve chicken humoral immunity. J Biomed Mater Res B Appl Biomater. 2009;91(2):621-625.

4. Miller PJ, King DJ, Afonso CL, Suarez DL. Antigenic differences among Newcastle disease virus strains of different genotypes used in vaccine formulation affect viral shedding after a virulent challenge. Vaccine. 2007;25(41):7238-7246.

5. Meulemans G, Gonze M, Carlier MC, Petit P, Burny A, Long L. Protective effects of $\mathrm{HN}$ and $\mathrm{F}$ glycoprotein-specific monoclonal antibodies on experimental Newcastle disease. Avian Pathol. 1986; 15(4):761-768.

6. Wang R, Doolan DL, Le TP, et al. Induction of antigen-specific cytotoxic T lymphocytes in humans by a malaria DNA vaccine. Science. 1998;282(5388):476-480.

7. Xu K, Ling ZY, Sun L, et al. Broad humoral and cellular immunity elicited by a bivalent DNA vaccine encoding HA and NP genes from an H5N1 virus. Viral Immunol. 2011;24(1):45-56.

8. Hallengärd D, Haller BK, Petersson S, et al. Increased expression and immunogenicity of HIV-1 protease following inactivation of the enzymatic activity. Vaccine. 2011;29(4):839-848.

9. Abbas AO, Donovan MD, Salem AK. Formulating poly(lactideco-glycolide) particles for plasmid DNA delivery. J Pharm Sci. 2008; 97(7):2448-2461.

10. Intra J, Salem AK. Fabrication, characterization and in vitro evaluation of poly(D,L-lactide-co-glycolide) microparticles loaded with polyamidoamine-plasmid DNA dendriplexes for applications in nonviral gene delivery. J Pharm Sci. 2010;99(1):368-384.

11. Wu H, Dennis VA, Pillai SR, Singh SR. RSV fusion (F) protein DNA vaccine provides partial protection against viral infection. Virus Res. 2009;145(1):39-47.

12. Wang T, Upponi JR, Torchilin VP. Design of multifunctional non-viral gene vectors to overcome physiological barriers: dilemmas and strategies. Int J Pharm. 2012;427(1):3-20.

13. Kim YC, Song JM, Lipatov AS, et al. Increased immunogenicity of avian influenza DNA vaccine delivered to the skin using a microneedle patch. Eur J Pharm Biopharm. 2012;81(2):239-247.

14. Conese M, Ascenzioni F, Boyd AC, et al. Gene and cell therapy for cystic fibrosis: from bench to bedside. J Cyst Fibros. 2011;10 Suppl 2: S114-S128.

15. Fowler V, Robinson L, Bankowski B, et al. A DNA vaccination regime including protein boost and electroporation protects cattle against footand-mouth disease. Antiviral Res. 2012;94(1):25-34.

16. Manoj S, Babiuk LA, van Drunen Littel-van den Hurk S. Approaches to enhance the efficacy of DNA vaccines. Crit Rev Clin Lab Sci. 2004; 41(1):1-39.

17. Sun J, Li D, Hao Y, et al. Posttranscriptional regulatory elements enhance antigen expression and DNA vaccine efficacy. DNA Cell Biol. 2009;28(5):233-240.

18. Gerdts V, Mutwiri G, Richards J, van Drunen Littel-van den Hurk S, Potter AA. Carrier molecules for use in veterinary vaccines. Vaccine. 2013;31(4):596-602.

19. Bottini M, D'Annibale F, Magrini A, et al. Quantum dot-doped silica nanoparticles as probes for targeting of T-lymphocytes. Int $J$ Nanomedicine. 2007;2(2):227-233.

20. Gerion D, Herberg J, Bok R, et al. Paramagnetic silica-coated nanocrystals as an advanced MRI contrast agent. J Phys Chem C Nanomater Interfaces. 2007;111(34):12542-12551.

21. Graf C, Dembski S, Hofmann A, Rühl E. A general method for the controlled embedding of nanoparticles in silica colloids. Langmuir. 2006;22(13):5604-5610. 
22. Meseguer-Olmo L, Ros-Nicolás M, Vicente-Ortega V, et al. A bioactive sol-gel glass implant for in vivo gentamicin release. Experimental model in Rabbit. J Orthop Res. 2006;24(3):454-460.

23. Radin S, El-Bassyouni G, Vresilovic EJ, Schepers E, Ducheyne P. In vivo tissue response to resorbable silica xerogels as controlled-release materials. Biomaterials. 2005;26(9):1043-1052.

24. Teoli D, Parisi L, Realdon N, Guglielmi M, Rosato A, Morpurgo M. Wet sol-gel derived silica for controlled release of proteins. J Control Release. 2006;116(3):295-303.

25. Dormer K, Seeney C, Lewelling K, Lian G, Gibson D, Johnson M. Epithelial internalization of superparamagnetic nanoparticles and response to external magnetic field. Biomaterials. 2005;26(14):2061-2072.

26. Arruebo M, Galán M, Navascués N, et al. Development of magnetic nanostructured silica-based materials as potential vectors for drugdelivery applications. Chem Mater. 2006;18(7):1911-1919.

27. Zhao W, Gu J, Zhang L, Chen H, Shi J. Fabrication of uniform magnetic nanocomposite spheres with a magnetic core/mesoporous silica shell structure. J Am Chem Soc. 2005;127(25):8916-8917.

28. Allouche J, Boissière M, Hélary C, Livage J, Coradin T. Biomimetic core-shell gelatine/silica nanoparticles: a new example of biopolymerbased nanocomposites. J Mater Chem. 2006;16(30):3120-3125.

29. Huo Q, Liu J, Wang LQ, Jiang Y, Lambert TN, Fang E. A new class of silica cross-linked micellar core-shell nanoparticles. J Am Chem Soc. 2006;128(19):6447-6453.

30. Tyner KM, Schiffman SR, Giannelis EP. Nanobiohybrids as delivery vehicles for camptothecin. J Control Release. 2004;95(3):501-514.

31. Zhao J, Fu X, Zhang S, Hou W. Water dispersible avermectin-layered double hydroxide nanocomposites modified with sodium dodecyl sulfate. Appl Clay Sci. 2011;51(4):460-466.

32. Yuan Y, Shi W. A novel LDH nanofiller intercalated by silsesquioxane for preparing organic/inorganic hybrid composites. Appl Clay Sci. 2012;67-68:83-90.

33. Kang H, Shu Y, Li Z, et al. An effect of alginate on the stability of LDH nanosheets in aqueous solution and preparation of alginate/LDH nanocomposites. Carbohydr Polym. 2014;100:158-165.

34. Zeng W, Shi X, Gao H, et al. Optimization of codon usage of F gene enhanced efficacy of Newcastle disease virus DNA vaccine. Chin J Anim Infecti Dis. 2009;17:8-16.

35. Sambrook J, Russell DW. Molecular Cloning: A Laboratory Manual. Cold Spring Harbor: Cold Spring Harbor Laboratory Press; 2001.

36. Zhao K, Zhang Y, Zhang X, et al. Preparation and efficacy of Newcastle disease virus DNA vaccine encapsulated in chitosan nanoparticles. Int J Nanomedicine. 2014;9:389-402.

37. Xu Y, Du Y, Huang R, Gao L. Preparation and modification of N-(2hydroxyl) propyl-3-trimethyl ammonium chitosan chloride nanoparticle as a protein carrier. Biomaterials. 2003;24(27):5015-5022.

38. Aksungur P, Sungur A, Unal S, Iskit AB, Squier CA, Senel S. Chitosan delivery systems for the treatment of oral mucositis: in vitro and in vivo studies. J Control Release. 2004;98(2):269-279.

39. Zhao F, Wu Y, Zhang X, et al. Enhanced immune response and protective efficacy of a Treponema pallidum Tp92 DNA vaccine vectored by chitosan nanoparticles and adjuvanted with IL-2. Hum Vaccin. 2011;7(10):1083-1089.

40. Kapczynski DR, King DJ. Protection of chickens against overt clinical disease and determination of viral shedding following vaccination with commercially available Newcastle disease virus vaccines upon challenge with highly virulent virus from the California 2002 exotic Newcastle disease outbreak. Vaccine. 2005;23(26):3424-3433.
41. Miller PJ, Estevez C, Yu Q, Suarez DL, King DJ. Comparison of viral shedding following vaccination with inactivated and live Newcastle disease vaccines formulated with wild-type and recombinant viruses. Avian Dis. 2009;53(1):39-49.

42. van Boven M, Bouma A, Fabri TH, Katsma E, Hartog L, Koch G. Herd immunity to Newcastle disease virus in poultry by vaccination. Avian Pathol. 2008;37(1):1-5.

43. Gurunathan S, Klinman DM, Seder RA. DNA vaccines: immunology, application, and optimization*. Annu Rev Immunol. 2000;18:927-974.

44. Borges O, Lebre F, Bento D, Borchard G, Junginger HE. Mucosal vaccines: recent progress in understanding the natural barriers. Pharm Res. 2010;27(2):211-223.

45. Jilek S, Merkle HP, Walter E. DNA-loaded biodegradable microparticles as vaccine delivery systems and their interaction with dendritic cells. Adv Drug Deliv Rev. 2005;57(3):377-390.

46. Waeckerle-Men Y, Groettrup M. PLGA microspheres for improved antigen delivery to dendritic cells as cellular vaccines. Adv Drug Deliv Rev. 2005;57(3):475-482

47. Zhao K, Li W, Huang T, et al. Preparation and efficacy of Newcastle disease virus DNA vaccine encapsulated in PLGA nanoparticles. PloS One. 2013;8(12):e82648.

48. Wang L, Chen D. A one-pot approach to the preparation of silver-PMMA "shell-core" nanocomposite. Colloid Polym Sci. 2006;284(4):449-454.

49. Liu H, Ye F, Cao H, Ji G, Lee JY, Yang J. A core-shell templated approach to the nanocomposites of silver sulfide and noble metal nanoparticles with hollow/cage-bell structures. Nanoscale. 2013;5(15):6901-6907.

50. Boyoglu S, Vig K, Pillai S, et al. Enhanced delivery and expression of a nanoencapsulated DNA vaccine vector for respiratory syncytial virus. Nanomedicine. 2009;5(4):463-472.

51. Hu Y, Jiang X, Ding Y, Ge H, Yuan Y, Yang C. Synthesis and characterization of chitosan-poly(acrylic acid) nanoparticles. Biomaterials. 2002;23(15):3193-3201.

52. Gupta PN, Khatri K, Goyal AK, Mishra N, Vyas SP. M-cell targeted biodegradable PLGA nanoparticles for oral immunization against hepatitis B. J Drug Target. 2007;15(10):701-713.

53. Ugwoke MI, Agu RU, Verbeke N, Kinget R. Nasal mucoadhesive drug delivery: background, applications, trends and future perspectives. $A d v$ Drug Deliv Rev. 2005;57(11):1640-1665.

54. Xu J, Dai W, Wang Z, Chen B, Li Z, Fan X. Intranasal vaccination with chitosan-DNA nanoparticles expressing pneumococcal surface antigen a protects mice against nasopharyngeal colonization by Streptococcus pneumoniae. Clin Vaccine Immunol. 2011;18(1):75-81.

55. Cripps AW, Kyd JM. Comparison of mucosal and parenteral immunisation in two animal models of pneumococcal infection: otitis media and acute pneumonia. Vaccine. 2007;25(13):2471-2477.

56. Russell PH, Dwivedi PN, Davison TF. The effects of cyclosporin A and cyclophosphamide on the populations of $\mathrm{B}$ and $\mathrm{T}$ cells and virus in the Harderian gland of chickens vaccinated with the Hitchner B1 strain of Newcastle disease virus. Vet Immunol Immunopathol. 1997; 60(1-2):171-185.

57. Reynolds DL, Maraqa AD. Protective immunity against Newcastle disease: the role of cell-mediated immunity. Avian Dis. 2000;44(1):145-154. 


\section{Supplementary material}

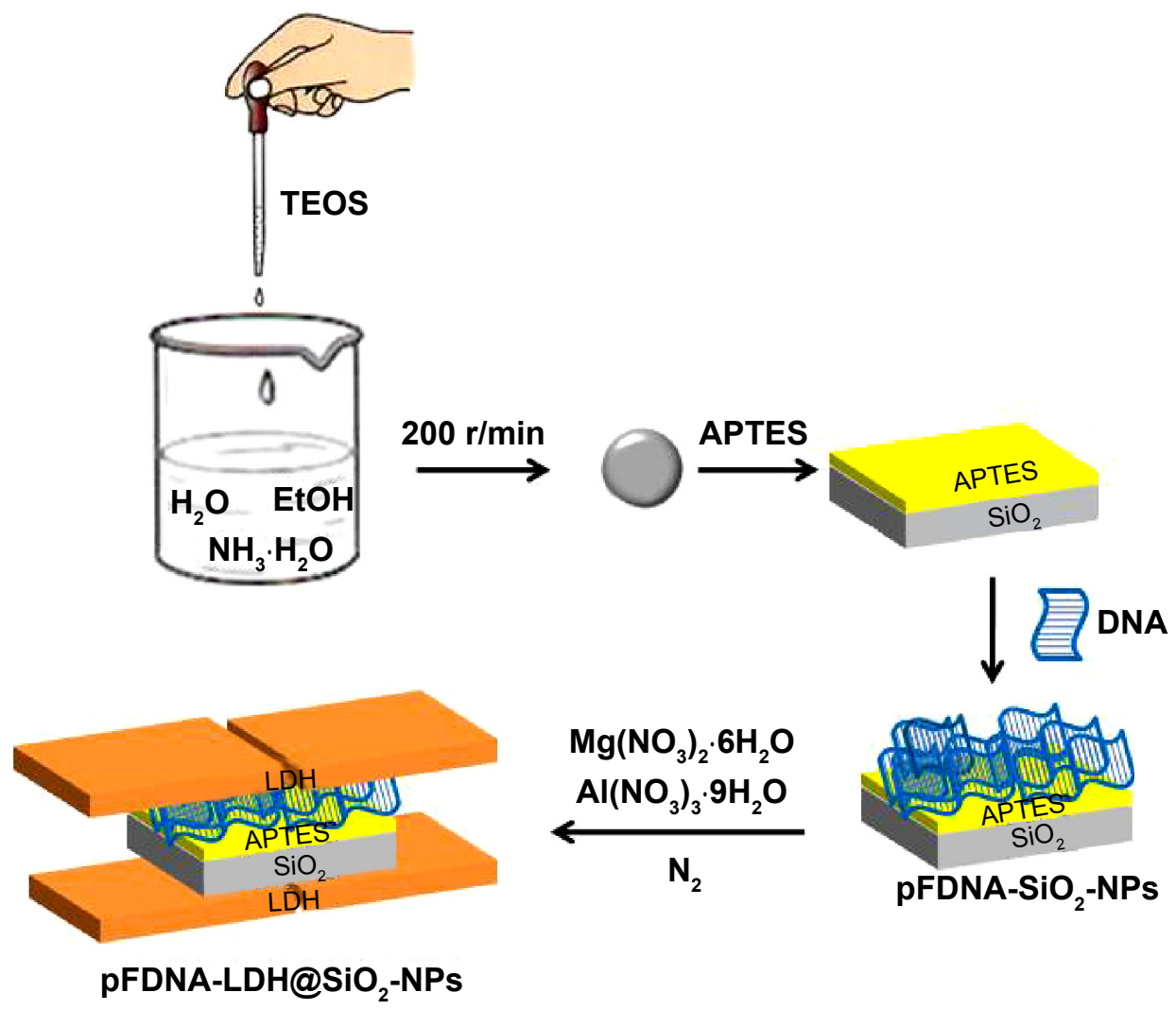

Figure SI Preparation of pFDNA-LDH@SiO2-NPs.

Abbreviations: APTES, 3-aminopropyl-triethoxysilane; LDH, layered double hydroxide; NPs, nanoparticles; pFDNA-LDH@SiO ${ }_{2}-N_{P s}$, Newcastle disease virus F gene encapsulated in ${\mathrm{LDH} @ \mathrm{SiO}_{2}-\mathrm{NPs} ; \text { pFDNA-SiO }}_{2}-\mathrm{NPs}$, Newcastle disease virus F gene encapsulated in $\mathrm{SiO}_{2}-\mathrm{NPs}$; TEOS, tetraethyl orthosilicate.

\section{Publish your work in this journal}

The International Journal of Nanomedicine is an international, peerreviewed journal focusing on the application of nanotechnology in diagnostics, therapeutics, and drug delivery systems throughou the biomedical field. This journal is indexed on PubMed Central, MedLine, CAS, SciSearch $®$, Current Contents $\AA /$ Clinical Medicine,
Journal Citation Reports/Science Edition, EMBase, Scopus and the Elsevier Bibliographic databases. The manuscript management system is completely online and includes a very quick and fair peer-review system, which is all easy to use. Visit http://www.dovepress.com/ testimonials.php to read real quotes from published authors. 